\title{
Evaluating the Spillover Effects of the Colombian Conflict in Ecuador ${ }^{1}$
}

\author{
José M. Fernández ${ }^{\mathrm{a}}$, Matteo Pazzona ${ }^{\mathrm{b}, \mathrm{c}}$ \\ ${ }^{a}$ Department of Economics, University of Bath, Bath, UK. \\ ${ }^{b}$ Department of Economics, Diego Portales University, Santiago, Chile. \\ ${ }^{c}$ Institute for Research in Market Imperfections and Public Policy, Santiago, Chile.
}

\begin{abstract}
The Colombian civil war lasted for nearly six decades with approximately ten percent of its population being displaced over the same period. The implications of this conflict has transgressed international boundaries. Countries such as Ecuador experienced an exodus of victims as well as an increase in the presence of armed groups, along with the proliferation of illegal businesses. Even though the internal social and economic consequences of the Colombian conflict have been documented in the literature, there is yet to be a study addressing these issues from the perspective of impacted neighboring countries. In this work, we contribute to the literature by evaluating whether the influx of asylum seekers and the increasing presence of armed groups in the bordering provinces of Ecuador have lead to an increase in violence among these provinces. We do not find any link between the arrival of asylum seekers and the incidence of violent crimes in the Ecuadorean bordering provinces. Similarly, our results indicate that despite an increase in the presence of armed groups, these regions did not experience an increase in the homicide rates significantly different from the other provinces. The results are robust to various specifications and econometric techniques.
\end{abstract}

\footnotetext{
${ }^{1}$ Pazzona would like to acknowledge the support by CONICYT, Programa POSTDOCTORADO under Grant 3160521; the Institute for Research in Market Imperfections and Public Policy under Grant ICM IS130002. A special thank to Paolo Buonanno, Alejandro Corvalan and Martin Rossi for useful suggestions. The authors also thank seminar participants at CIDE, Aguas Calientes, Mexico, University of Montevideo, Uruguay; Socher Conference, Viña del Mar, Chile; LACEA, Sao Paolo, Brasil; University of Chile, Santiago de Chile, Chile; University Diego Portales, Santiago de Chile, Chile and Pontificia Universidad Católica del Ecuador, Quito, Ecuador.
} 
Keywords: Ecuador, Spillover effects, Colombian conflict, Violence and Asylum Seekers. JEL Classification: D74, K42, J15 and O54, . 


\section{Introduction}

On November 30, 2016 Colombia's Congress approved a peace deal between the Revolutionary Armed Forces of Colombia (FARC) and the Colombian government. ${ }^{2}$ This was an important step forward to end an armed conflict which spanned for over six decades and had a significant human cost in the country. According to Centro de Memoria Histórica (2017), from 1958 until 2012 there has been approximately 218,094 casualties, of which $81 \%$ were civilians, and over 5,712,506 were displaced people which corresponds to over ten percent of the country's population from 1985 up to 2012 (CODHES, 2012). In addition to the human impact of the conflict, a number of authors have also studied the social and economic impact associated with the conflict (Ibáñez and Vélez, 2008; Camacho and Rodriguez, 2013; Morales, 2016; Calderón-Mejía and Ibáñez, 2016). However, the conflict was not solely confined within the Colombian borders, and the social and economic ramifications from the conflict soon spilled over into the neighbouring countries, such as Ecuador and Venezuela (Deas, 2011). By the early parts of the century, as a consequence of the implementation of the Plan Colombia, the conflict intensified and neighbouring countries began to absorb a series of social and economic spillover effects (Martinez, 2017). For example, Venezuela and Ecuador welcomed victims seeking refugee status and consequently saw an increase in the presence of armed and illegal groups operating in their territory (USG, 2009). As a result, Ecuador had become the largest recipient of refugees in Latin America by 2012 (ACNUR, 2015). These factors have created significant tensions both within Ecuadoreans but also towards the Colombian refugee population. ${ }^{3}$ This has been the source of animosity and discrimination against the asylum seekers who also became the source of blame for the increasing crime rates, particularly along the bordering provinces of Ecuador (El Comercio, 2010b). ${ }^{4}$

\footnotetext{
${ }^{2}$ There is evidence that the conflict is far from over. Recently, a report by the Guardian Newspaper cited that new armed groups and long-established ones are violently occupying the regions left behind by the FARC, in order to get control of the cocaine trade, illegal gold mines and other criminal enterprises which were in the hands of the FARC prior to the peace deal (The Guardian, 2017) .

${ }^{3}$ We use the terms Asylum Seeker and Refugee interchangeably along our study. However, conceptually we understand that these terms refer to people under different status.

${ }^{4}$ In a study by Ospina and Santacruz (2011), the authors found that $64 \%$ of Ecuadoreans have a "bad" or "very bad" opinion about Colombian refugees in the country.
} 
Yet, only a few studies have attempted to address the impact of the Colombian armed conflict in the neighbouring countries. Only recently, Martinez (2017) addressed this issue by evaluating how guerrilla activities increased in the region after Hugo Chávez was elected as the president of Venezuela. However, to our knowledge, there has been no published study that systematically addresses the possible spillover effects through which the Colombian conflict may have impacted the security levels in Ecuador. In this context, our work enhances the current body of literature, by evaluating the extent to which the intensification of the Colombian conflict impacted the incidence of violence in Ecuador. We explore this hypothesis by means of two possible channels through which violent crime rates may have been affected in the bordering provinces of Ecuador: (1) the presence of asylum seekers; (2) the presence of armed and illegal groups operating in these territories. The two types of spillovers, the "Asylum Seekers Spillover" and the "Conflict Spillover", were mainly concentrated in the northern region of Ecuador. Colombian guerrillas and illegal groups were mainly based in the Ecuadorean bordering provinces of Sucumbios, Carchi and Esmeraldas. Initially, the asylum seeker population was located along the bordering provinces of Ecuador. Gradually began to relocate to larger cities across the country. The press, general public and the Ecuadorean government singled out the influx of asylum seekers and increasing illegal activities by the guerrilla groups as the leading cause of the perceived high level of violence (El Universo, 2010; Ospina and Santacruz, 2011). For instance, in 2010, the vice president of Ecuador at the time and also the current president elect, Lenin Moreno said: "Before, the criminals were not violent and the robberies were rare...crime was brought in from abroad" (El Espectador, 2010a). In the same report, Mr. Moreno also added: "the people who deserted the FARC and paramilitaries are used to commit crimes and came to our country to train criminals in Ecuador." We believe that this is the first study which empirically addresses the policy relevance of these concerns. Consequently, our aim is to investigate whether each of the spillovers contributed to the rising incidence of violent crimes in Ecuador.

In order to conduct the empirical analysis, we have built a panel data at the provincial level for Ecuador. As a measurement of violence, we employ homicide rates which is a standard measure in 
the conflict literature. ${ }^{5}$ Given the likely endogeneity of our measurement of the migration variable, we apply an instrumental variable approach. The results show that the asylum seekers did not have a crime-increasing effect. On the contrary, we conclude that the wave of asylum seekers is associated with a reduction of violent crime rates in the region. Our results contribute to the recent literature that studied the link between the presence of asylum seekers and the level of violence in the hosting country (Bell et al., 2013; Couttenier et al., 2016a).

In effort to identify the "Conflict Spillover", we consider the rate of conflict related-events as treatment variable in the Colombian municipalities adjacent to the border with Ecuador. ${ }^{6}$ In our baseline specification, we impute such treatment variable to the three bordering Ecuadorean provinces with Colombia: Sucumbios, Carchi and Esmeralda. The assumptions behind this measure depends on the fact that the spillover effects co-move with the conflict in Southern Colombia. Our results suggest that the "Conflict Spillover" did not lead to an increase in violence in the Ecuadorean bordering provinces. This finding is robust to various definitions of the 'treated' units and spillover effects. Moreover, we conduct various econometric specifications and vary time frames and all the results suggest a null effect. The increased presence of illegal groups and the flourishing drug market in northern Ecuador did not lead to an increased violence, proxied by the homicide rates.

In summary, the asylum seeker channel can be excluded as an indirect effect of the Colombian conflict on the increasing incidence of violence in Ecuador. The no-effect of the "Conflict Spillover" might suggest that Ecuador has only been used as a transit point for drug trafficking operations where criminal organizations have not been interested in engaging in violent activities. There is significant evidence in the literature highlighting the fact that, under certain conditions, organized groups who manage illegal businesses do not always resort to the use of violence as their modus operandi. For instance, Castillo et al. (2012); Dell (2015) have provided evidence of this type of behavior during the Calderon administration in relation to the drug trafficking dynamics in

\footnotetext{
${ }^{5}$ Dix-Carneiro et al. (2016) showed that homicide rates is a good proxy for the overall level of crime in Brazil.

${ }^{6}$ There is no data available for Ecuador at the national nor provincial level that would allow us to capture the "Conflict Spillover."
} 
Mexico. This is an area of research which could be explored in future.

The paper is organized as follows: Section 2 presents an overview of the historical background of the spillover effects of the Colombian conflict in Ecuador along with the relevant literature review. Section 3 presents the data definitions and limitations. Section 4 reveals and discusses the empirical results. Section 5 concludes.

\section{Historical Background and Literature Review}

The Colombian conflict has been going on for many decades now and it involves illegal versus state actors (Daza and Rodríguez, 2012). Among the former, there are guerrilla groups, such as the FARC and Ejército de Liberación Nacional (ELN), which have traditionally being left-wing. There are also paramilitary ones, such as the right-wing paramilitary groups AUC, which were created by landlords with the specific task of protecting their interests. Indeed, FARC has been the prominent group as it accounts with the highest number of members. This group was able to thrive because it directly managed the coca business, unlike other groups, as ELN. On the other hand, the state has been trying to marginalize these illegal groups, especially in the rural areas. The conflict got even harsher as the result of the implementation of the Plan Colombia. The plan was a joint effort of the Colombian and the U.S. government to neutralize, among other things, organized crime groups that control coca cultivation for illegal drug production and trafficking in Colombia. $^{7}$ One of the main strategic objectives of Plan Colombia was to reduce the cultivation, processing and distribution of narcotics by $50 \%$. In order to achieve this goal, the Plan Colombia included several campaigns to destroy the production and processing of cocaine that included aerial spraying, manual eradication and control of chemical precursors used in the production of cocaine, the detection and destruction of cocaine processing laboratories, and seizing of drug shipments en

\footnotetext{
${ }^{7}$ The comprehensive strategy was designed to address five areas of action: (1) development of productive processes; (2) protection and promotion of human capital and humanitarian assistance; (3) institutional development and strengthening of social capital; (4) construction of an infrastructure for peace; (5) and promotion of a sustainable environment.
} 
route to other countries (Mejia et al., 2015). ${ }^{8}$ For the purposes of this work, it is worth mentioning that the areal fumigation of Colombia at the border with Ecuador created strong diplomatic tension between the two countries because the Ecuadoreans alleged that the fumigations caused serious health problems to the population at the border. ${ }^{9}$ This strategy fueled the Colombian conflict by further militarizing the confrontation between legal and illegal groups (El Espectador, 2010b).

The conflict had a significant cost within Colombia: it destroyed entire villages, it induced forced migration, and created a constant feeling of insecurity. For instance, Ibáñez and Vélez (2008) estimate the social welfare loss (by household) from displacement to be substantial and about $37 \%$ of the net present value of rural lifetime aggregate consumption. Even if Colombia suffered the most of its own conflict, neighbor countries also suffered from its unintended consequences. Ecuador is probably the country which has been mostly affected. ${ }^{10}$

\subsection{Asylum Seekers Spillover}

Asylum seekers begin to seek refuge in Ecuador after the year 2000, right after beginning of the implementation of the Plan Colombia. This strategy included several campaigns to destroy the cultivation of coca leaves, the production, processing and distribution of cocaine. The offensive carried out by the Colombian armed forces also intensified the conflict between illegal groups who wanted to defend their territory and the state actors. Poor villagers were caught in the middle of the conflict and forced to leave their houses. Many of them moved to other Colombian municipalities but many others relocated abroad (Ibáñez and Vélez, 2008). Since the Colombian conflict was more intensive in the souther region of Colombia, it was natural for many Colombians to seek refuge in neighboring Ecuador. According to official figures from the UNHCR (2017), Ecuador

\footnotetext{
${ }^{8}$ The Plan Colombia has been a source of stiff arguments about its effectiveness to achieve peace and combat drug trafficking in the region (Beittel, 2011). Even though during this period the strategy was able to reduce by 50\% the area of coca leaf cultivation, it was not able to reduce amount of coca leaf production itself (Gerson and Perez, 2012; Mejia and Posada, 2008; Mejia and Restrepo, 2013; Reyes, 2014). Mejia et al. (2015) concluded that spraying one additional hectare reduces coca leaf cultivation by about 0.2 to 0.65 hectares. On the other hand, other authors label the Plan Colombia "an extremely effective strategy" (Beittel, 2011).

${ }^{9}$ This claim has been recently supported by 17 experts from 11 countries from the International Agency for Research on Cancer has labeled Glyphosate (coca eradication herbicide) as "probably carcinogenic to humans" (Guyton et al., 2015).

${ }^{10} \mathrm{Here}$, for simplicity, we focus on those that might directly affect the level of violence in Ecuador.
} 
quickly became the country receiving the most displaced people from the Colombian conflict. The first waves of asylum seekers started settling along the bordering provinces with Ecuador (i.e. Sucumbios, Carchi and Esmeraldas) in the early years of the 2000s. Slowly, they also moved to other regions, even far from the border. Another peak of the influx of asylum seekers is 2009, following a Colombian cross-border strike into Ecuadorean territory which resulted in the death of FARC leader Raúl Reyes the previous year. ${ }^{11}$ Therefore, the spillover effect does not overlap exactly with the presence of illegal groups.

Asylum seekers were often considered as crime-prone and perpetuating violent acts by the local population. However, no works empirically verified whether there is a causal relation between these variables for Ecuador. Our analysis fits into the literature that links the presence of asylum seekers with violent behavior in the hosting countries. The closest paper to ours is the one by Bell et al. (2013) which considered the impact of two migration waves on crime rates for the UK in the 2000s. The first wave was composed by asylum seekers escaping from war infested countries. ${ }^{12}$ The authors did not find a significant effect of asylum seekers on violent crimes. Another one is Couttenier et al. (2016b) which studied the criminal behavior of asylum seekers in Switzerland. The authors found that those who were exposed to civil conflicts/mass killings in their childhood were more likely to commit crime than the other asylum seekers. Interestingly, when offered labor market access these differences were vanished. On a similar theme the paper by Miguel et al. (2011) that showed that football players that grew up in countries with civil wars were more likely to behave violently on the pitch. Our paper also fits in the literature that study the impact of refugees, and displaced people, on various socio-economic outcomes (Ibáñez and Vélez, 2008). As we will see shortly, our findings do not suggest any evidence of a positive relationship between crime and asylum seekers.

\footnotetext{
${ }^{11}$ Also in 2008, the death from a heart attack of Manuel Marulanda Velez, known as 'Tirofijo' and main leader of FARC.

${ }^{12}$ The second one started in 2004, when eight new countries joined the European Union.
} 


\subsection{Conflict Spillover}

As a consequence of the intensification of the conflict, many cells of illegal groups started crossing the border to escape the repression of the Colombian government. In particular, journalistic evidence show how FARC groups have been operating in Northern Ecuador for many years. As early as 1996, there were reports of FARC operating in Ecuador through smuggling guns and finding "Safe Havens" inside Ecuadorean territory (El Tiempo, 1999; El Nuevo Diario, 2008; El Universo, 2016). Those groups installed camps close to the border with Colombia, but in the Ecuadorean provinces. However illegal, these camps were used for the most part as training and logistical resupply as well as planning attacks the Colombian army (United States Department of State, 2010). However, they also started consolidating their criminal power in bordering provinces by increasing their drug and the illegal arms distribution in the region (El Comercio, 2015). The FARC are also thought to have recurred to targeted executions, death threats and forced recruitment (FES, 2006). At first, the presence of FARC in these provinces was underestimated by the Ecuadorean government and there were a few confrontations between them. However, after the Operación Fenix (Phoenix Operation) in 2008, where Colombian forces attacked a well-established encampment in the Ecuadorean jungle. During this event the army killed over twenty militants, including the FARC commander Luis Édgar Devia Silva, known by the "nom de guerre" Raúl Reyes. Such event created a diplomatic crisis between the two neighbor countries and forced the Ecuadorean government to deploy more resources to the region counteract the incursions by the guerrillas. ${ }^{13}$ However, FARC was not the only illegal groups operating in Ecuador. A report by the General Attorney Office of Ecuador also cites a number of incursions by AUC groups as the Aguilas Negras and Los Urabeños (FGE, 2014). ${ }^{14}$ Nevertheless, and despite the increasing presence of illegal groups, Ecuador had never been considered a major drug producing country, but as

\footnotetext{
${ }^{13}$ Something similar happened in Venezuela. Martinez (2017), pag. 12 says "In 2010 the Colombian government divulged satellite images of alleged FARC camps inside Venezuela at an OAS summit (BBC News, 2010a). Colombian intelligence reports estimated at the time that FARC could have over 1,500 of their members distributed among 28 camps inside Venezuela (El Espectador, 2010b).

${ }^{14}$ These are organized gangs that control fluvial routes in the border provinces between Ecuador and Colombia for cocaine transportation and distribution.
} 
a major transit for drugs from Colombia to the United States and Europe (Youngers, 2004).

The increased presence of illegal groups in Ecuador also coincided with the spread of drug business into Ecuador. A recent report by Ecuador's Attorney General reveals the extent to which the production and distribution of cocaine has been diverted to Ecuador's national territory in particular to the provinces of Carchi, Esmeraldas and Sucumbios (FGE, 2014). For example, the document cites that in August 2012 alone a joint police operation between Ecuadorean and Colombian policy forces dismantled seven cocaine laboratories in Esmeraldas, Ecuador. Many of the illegal groups mentioned earlier, led by FARC, started managing the drug business, as they were doing in Southern Colombia. The combination of the presence of illegal groups and a drug market were seen by the Ecuadorean press and public opinion as creating favorable ground for violence. For example a report by the newspaper "El Comercio" in July, 2010 cites that a great deal of the violence seen in the province of Esmeraldas, Ecuador is due to the presence of drug trafficking activities by the Colombian drug trafficking group "Águilas Negras" (The Black Eagles) (El Comercio, 2010a).

\section{Data}

\subsection{Presentation of the Panel Data and Measurement of Violence}

Our purpose is to analyze the possible causal effects of two well-documented spillover effects, Asylum seekers and Conflict, of the Colombian internal armed-conflict on the level of violence in Ecuador. In order to conduct this study, we have created two panel datasets from 1997-2012 and from 2000-2012 at the provincial level in Ecuador. ${ }^{15}$ In Table 1 we provide a summary statistics for the variables of interest and Table 2 we describe in detail each variable used in the empirical section.

\footnotetext{
${ }^{15}$ In our dataset we have considered the original 20 provinces as they existed in Ecuador prior to 1999 (excluding the Galapagos Islands). In 1998 the province of Napo was split into two: Napo and Orellana; for a total of 21 provinces. Moreover, after the constitution of 2008, the political administrative division of Ecuador changed and two provinces were also split into two (i.e Pichincha-Santo Domingo de los Tsachilas and Guayas-Santa Elena) for a total of 24 provinces (including the Galapagos Islands). For consistency across our sample, we have assumed the political administrative division prior to 1999 for the entire analysis. Moreover, we have not considered the Galapagos Islands in our study given its extreme distance from the mainland.
} 


\section{[ Table 1 and Table 2 ABOUT HERE]}

As a measurement of the overall incidence of violence in Ecuador, we use homicide rates computed from the mortality records. This information has been accessed from the "Deaths and Births Statistical Yearbook" (Anuario de Nacimientos y Defunciones) published by Ecuador's National Institute of Statistics and Censuses (INEC, 2017b). This dataset contains individual records of deaths by external causes according to the International Statistical Classification of Diseases and Related Health Problems 10th Revision (ICD-10). ${ }^{16}$ The data set records the cause of death as registered in the death certificate as signed by the medical examiner. We aggregate this information to the provincial level from 1997 to 2012.

We are aware that homicides rate is not the only form of violent crimes. In fact, one could argue that violent crimes, other than homicides, are more prevalent in the society. ${ }^{17}$ Nevertheless, in the context of a developing country, we are confident on the relevance of homicide rates as a measurement of violence and particular given that this measurement of violence suffers less from underreporting relative to other forms of violent crimes (Soares, 2004b).

\subsection{Asylum Seekers Data}

The displacement of Colombian citizens seeking refuge in Ecuador, derived from the intensification of the conflict, has been an important social and economic factor along the bordering provinces of Ecuador. Even though the majority of the displaced population relocated within Colombia, a significant number of the victims sought refugee in neighboring countries and the majority of them relocated in Ecuador. According to official figures from the United Nations Human

\footnotetext{
${ }^{16}$ We use the ICD-10 for "External causes of morbidity and mortality" classification X85-Y09 for Assault.

${ }^{17}$ Unfortunately, access to this information has proven to be impossible to access in Ecuador. We have made a number of requests to Ecuador's Police department and the Ministry of Interior for access to data on other forms violent crime statistics were refused. In addition, even if the data would have been provided, from our experience, Ecuador's Police department does not have in place a systematic data compilation that dates back to the mid-late 1990s at the provincial level. We also attempted to collect records for other forms of violent crimes from the Ministry of Justice, but we were told that their dataset only contained information on crimes that had been processed by the entity and it also contained double-counting since multiple people could be charge with the same crime. Additionally, the reporting and collection of this data was likely not going to be a random sample of the crimes across provinces since it depends on the institutional settings particular of each province. Moreover, the data dating back to 1997 at the provincial level was likely to exist.
} 
Rights Council (UNHRC), Ecuador has the highest number of refugees in Latin America with estimates of 8 out 10 Colombian asylum seekers in the world, at a rate of 1500 per month, requesting international protection in Ecuador (ACNUR, 2011).

We are interested in determining whether the influx of asylum seekers, as a consequence of the intensification of the conflict, had a causal effect on the incidence of violent crime rate in the hosting Ecuadorean provinces. The variable of interest is Asylum Seekers and it represents the total stock of asylum seekers per 100 inhabitants at the provincial level. An asylum seeker is a person that has applied to receive the refugee status. ${ }^{18}$ The data on asylum seekers and refugees at the provincial level have been provided through requests to the Ecuadorean Ministry of Foreign Affairs (Ministerio de Relaciones Exteriores y Movilidad Humana). ${ }^{19}$

\section{[Figure 1 ABOUT HERE]}

Figure 1 shows the flow of total number of asylum seekers in Ecuador from 1997 to 2012. From Figure 1, we observe the that there are two waves of asylum seekers in this period. The first wave of asylum seekers occurs in 2002 a year after the implementation of the Plan Colombia. After 2002, we see a gradual decrease in the number of asylum seekers before the number of refugees began to increase again after 2006 up to 2009 when the second wave of asylum seekers peaks. The peak of asylum seekers in the events we have mentioned in the Section 2.1.

In Figure 2 we show the progression of Asylum Seekers per capita into Ecuador across provinces from 1997 to 2012. In the early years after the implementation of the Plan Colombia, asylum seekers began settling along the bordering provinces with Ecuador (i.e. Sucumbios, Carchi and Esmeraldas). Gradually, many have also settled across other Ecuadorean provinces relatively close to the border such as Imbabura. Also, we see a progression towards Pichincha, which is the province where Quito, the capital of Ecuador is located. ${ }^{20}$ By the end of 2012, Pichincha had the highest

\footnotetext{
${ }^{18} \mathrm{We}$ also have data on the total number of refugees in the country. The difference between the two is that asylum seekers consider all applicants to receive refugee status whereas refugees are only the people with that legal status in the country.

${ }^{19}$ This data is not publicly available and has been granted for academic purposes only.

${ }^{20}$ Both Imbabura and Pichincha are within two and four hours driving distance from the closest border with Colombia.
} 
absolute number of asylum seekers. Nevertheless, per capita, the bordering provinces of Ecuador constantly remained the highest recipients of asylum seekers relative to the rest of the provinces.

\section{[ Figure 2 and Figure 3 ABOUT HERE]}

A critical point of contention is that the total number of asylum seekers could be very mixed at the country and provincial level and not representative of the overall effect of the displacement of Colombian citizens to Ecuador. Ideally, we would have liked to have acquired information on asylum seekers data and their national origin. We do not have data on the country of origin for asylum seekers and refugees at the provincial level, but only at a national level. In Figure 3, we show the evolution of asylum seekers from all nationalities in Ecuador from 2000 to 2012. From Figure 3, it is evident that the great majority of asylum seekers during this period are from Colombian origin. In fact, from 2000 to 2012 over $98 \%$ of asylum seekers were Colombians nationals. Despite the data scarcity, it is evident that using the total number of asylum seekers in Ecuador appears to be an indicator of the displacement of Colombians to Ecuador as a consequence of the armed conflict.

\section{[Figure 3 ABOUT HERE]}

\subsection{Conflict Measure}

As a measure of the spillover effect, we would have liked to employ the number of deaths for which the FARC are responsible or the number of coca laboratories destroyed in Ecuadorean territory. Unfortunately, this data is not available at the provincial level with a yearly frequency nor at a more aggregate level. Even the data were available, these events are not very frequent and likely not to be random. Therefore, we are forced to identify the presence of illegal groups and drug businesses in an indirect way. Therefore, the first choice we make is to identify the 'treated'

provinces or the provinces affected by these events. Historically, armed groups have operated very close to the international border with Colombia, in the three northern Ecuadorean provinces 
(Sucumbios, Carchi and Esmeralda). Particularly, all the discovered camps were in one of the three provinces. Consequently, in the baseline regression we will consider only the bordering three provinces to be affected by the two spillover or receiving the treatment effect. ${ }^{21}$ Consequently, we concentrate the analysis in these provinces.

For our study, we need to find a measurement of the presence of illegal groups and drug related businesses. In our efforts, we exploit exploiting the fact that there is a strong relationship between illegal group presence, mainly FARC, and the and the intensity of the Colombian conflict. According to sources cited by Martinez (2017), one of the FARC commanders, Raúl Reyes, had moved to Ecuadorean territory as early as 2003 as the military operations against the insurgents by the Colombian government intensified. Coincidentally, we see a rise in FARC attacks, which we argue is a consequence of the intensification of the conflict in an effort to gain and maintain the territory in response to the pressures imposed by the Colombian army. Moreover, there is a strict relationship between the intensification of the conflict in Colombia and the increase of the drug trafficking activities in the northern bordering provinces of Ecuador with Colombia. Even though we do not have drug trafficking activities at the provincial level in Ecuador, we have reference data at the national level obtained from UNODC (2017). We use the data at the national level and compare it with the level of conflict in southern municipalities of Colombia with the tons of cocaine seizure in Ecuador.

Although we only have data at the national level, we can compare the level of conflict in southern Colombia with the tons of cocaine seizure in Ecuador. ${ }^{22}$ In Figure 4, we graph the FARC related events and the amount of cocaine seizures in Ecuador at the national level. From Figure 4, the amount of cocaine seizures appears to be increasing as the intensification of the conflict in Colombia increases. This suggests that the guerrillas, in response to the intensification of the conflict in Colombian territory, sought alternative routes for their drug distribution operations.

\section{[Figure 4 ABOUT HERE]}

\footnotetext{
${ }^{21}$ As further exercises, we will consider the treated units in a different way.

${ }^{22}$ There is not data available for cocaine salts, paste and base for the year 2000 .
} 
To sum up, we claim that we can proxy the presence of illegal groups and the drug activity by the level of conflict in southern Colombia. In order to do so, we need information on the conflict in this area. Fortunately, there exist very detailed data on the conflict at the municipal Colombian level and for a long period of time. Our strategy is based on the following steps: first we calculate a measure of conflict, which will describe shortly, for the Colombian municipalities right at the border with Ecuador by year. These municipalities are in red in the Figure 5. Then we assign this measure to the three Ecuadorean provinces, which in the map are blue. At least at the beginning, the yellow Ecuadorean provinces have zero level of spillovers. We will try various specifications, but, the baseline is the one we have just described.

Data on Colombian conflict were taken by the 'Centro de Estudios sobre Desarrollo Económico' (CEDE) of the University of Los Andes in Bogota. The sources employed by this centre are mainly the National Department of Planning (Departamento Nacional de Planeación- DNP) and the Observatory on Human Rights (Observatorio de Derechos Humanos). ${ }^{23}$ Both agencies gather information from the National Police and from newspaper reports. This database provides official information on the activities of illegal gangs (FARC, ELN and AUC) at the municipal level for most of the 1,102 municipalities since $1993 .^{24}$ Given the richness of data until 2010 and the fact that the presence of illegal groups dates back earlier than 2000, our panel covers the period 19972010. We included the 24 indicators which that are available for this period. These ranges from homicides to attacks against the population. ${ }^{25}$

\section{[Figure 5 ABOUT HERE]}

Based on such indicators, we constructed various measures of conflict, which represent our treatment variable. In our preferred one, we sum all the indicators that refer to FARC for all the municipalities that share a border with Ecuador and then we weight by the total population. We

\footnotetext{
${ }^{23}$ This organization is managed by the Office of theVicepresident of Colombia.

${ }^{24}$ Fortunately, all the municipalities we are interested on, have data.

${ }^{25}$ All 24 indicators are: loss of guerrilla member, demobilized member, murder of civilian, political assassination, wounded people, loss to army, confrontation with army, ambush, harassment, terrorist act with explosive, incendiary terrorist act, offensive action, assault to population, raids to the population, assaults to private property, political attack, attack against installation, roadblocks, terrestrial piracy, illegal checkpoint and attack against population.
} 
label this variables as FARC event rate . The choice of using only the Colombian municipalities bordering with Ecuador is due mainly for two reasons. On the one hand, we want to consider spillovers from areas as close as possible to Ecuador. We preferred excluding conflict level in areas very far from the Ecuadorean border. On the other hand, in the coca producing regions of Putumayo and Nariño, FARC is by far the dominant group. Our measure of conflict closely follow the ones employed by Acemoglu et al. (2013) and Martinez (2017), who also considered data from CEDE. Both works summed conflict-related events and weighted this measure by the average population (Acemoglu et al., 2013) or the initial population (Martinez, 2017). We multiply this time-varying variable with a dummy equal one for each of the three Ecuadorean bordering provinces, and call it Bord FARC $C_{i, t}$. All the provinces that are not bordering get a zero value.

In a similar fashion, we construct the variable Bord $A l l_{i, t}$ which sums all the events which refers to FARC, ELN and AUC, weighted by the population. Bord FARC Nei $i_{i, t}$, considers the "conflict rate" for all the municipalities at the border plus those that share a border with these ones (color orange in Figure 5). Bord All Nei, considers all events by FARC, AUC and ELN. The fact that Bord $F A R C_{i, t}$ is the same for all the bordering provinces is a limitation of the data. Taking this into consideration and with the aim of having more granular data for each bordering provinces, we also created the variable, Bord FARC Het $t_{i, t}$ which assigns a different conflict rate to each Ecuadorean provinces depending to the municipalities that share the border within Colombia. Bord All Het ${ }_{i, t}$, considers also their neighbor municipalities. In Figure 6, we plotted the homicide rates for the three bordering provinces versus the not bordering ones for all the years of the panel. In the same graph we plot the variable Bord $\operatorname{Farc}_{i, t}$. First, we note that homicides in the northern provinces are higher than the other ones. Secondly, homicide rates in the bordering provinces seems to follow closely the trend of Farc Event Rate compared to not bordering ones. Such correlation seems to be stronger for some years than others. Nevertheless, we need to rely on the econometric analysis to test such visual inspection, .

[Figure 6 ABOUT HERE] 


\subsection{Control Variables}

The crime literature proposes two potential explanatory categories for the incidence of violent crimes in Latin America. In general, these are: (1) the social and economic conditions propitious to the engagement in criminal activities by a larger fraction of the population; (2) the governmental and institutional settings designed to prevent and repress criminal activities. In our empirical analysis we include a measurement for each of these categories (Soares and Naritomi, 2010).

Demographic factors are associated with the age structure and socioeconomic conditions of the population. Moreover, the literature from criminology has shown that both perpetrators and victims of violent crimes tend to be young (Soares and Naritomi, 2010). Thus, in line with the empirical literature of crime, we include a series of demographic factors such as the population density, the percentage of young people, the percentage of male and the percentage of young-male at the provincial level from 1997 to 2012 (INEC, 2017c). ${ }^{26}$

A number of empirical studies have found evidence of the correlations between the economic performance and inequality with several measurements of crime rates in Latin American countries (Bourguignon et al., 2003; Soares, 2004a). ${ }^{27}$ However, the relationship between income and violent crime is far from clarified. For instance in cross country studies, Fajnzylber et al. (2002a,b) showed that the average income does not have an impact on violent crime (including some Latin American countries): The authors could show only a significant effect of income inequality. ${ }^{28}$ Ideally, we would have liked to obtained data on the economic performance and inequality, but none of these variables exist up to date at the provincial level for the time period of interest. Moreover, Ecuador changed the methodology to compute its GDP in 2007 and even though there exists a series for GDP from 2000 to 2006 it is not comparable with the current series published by the Central Bank and it is not available at the provincial level. Given the limited availability of economic performance data in the country, we have decided to construct a variable to proxy for economic performance at the provincial level. We use the total number of newly registered vehicles as a

\footnotetext{
${ }^{26}$ Please refer to Table 2 more detail information of the definition and sources for these variables.

${ }^{27}$ Soares and Naritomi have also indicated that there are other economic indicators which might matter more.

${ }^{28}$ We thank an anonymous referee to suggesting this point.
} 
proxy for the level of income at the provincial level. Particularly, we define the Income Proxy at province ' $i$ ', at time ' $t$ ', as the total number of new registered vehicles at time ' $t$ ' with model-year ' $t$ ' or ' $t+1$ ' per 100,000 inhabitants. ${ }^{29}$ The data used to construct the Income Proxy was obtained from the "Yearbook of Transport Statistics" (Anuario de Estadística de Transporte) published by INEC (2017a). In Table 3 we have calculated the correlations between GDP and the Income Proxy across time by province. There, we show that the correlation coefficients between Income Proxy and GDP well exceeds 0.90 for most provinces except for Azuay, Cañar and Carchi. These results indicate that, during this period, changes in the stock of new vehicles are strongly associated with fluctuations in GDP. ${ }^{30}$ Therefore, from the correlation results, we feel confident to assume that the Income Proxy is a suitable proxy for GDP for the entire period of the analysis given the strong correlation between these variables.

\section{[Table 3 ABOUT HERE]}

The other relevant factor in determining the incidence of violent crime is the strength and effectiveness of the repressive policies implemented by the government. The government policies adopted to decrease violent crime rate include incarceration of offenders and harsher penalties for criminals, large police forces, effective judicial systems, and, overall the respect to the law enforcement and judicial institutions. As a deterrent variable we employed the total the number of prison population per 1,000 inhabitants at the provincial level. In our case, and due to data limitations in Ecuador, this data only covers the period from 2000 to 2012 at a provincial level. This variable is a standard proxy frequently used in the literature of crime (Levitt, 1996).

\footnotetext{
${ }^{29}$ For example, for the year 2006, we only consider new registered vehicles whose model-year are 2006 and 2007.

${ }^{30}$ Given the fact that we do not have a GDP series at the provincial level from 2000 to 2006, we would have to further assume that the general trend between these variable did not significantly change during this period.
} 


\section{Empirical Analysis}

\subsection{Asylum Seekers Spillover: Impact of Asylum Seekers on Violence}

Our analysis begins by examining the relationship between Asylum Seekers and the murder rate between 1997 to 2012. Formally, we test the following model:

$$
\text { MurderRates }_{i, t}=\beta \text { AsylumSeeker } s_{i, t}+\alpha \text { Control }_{i, t}+\zeta_{i}+\theta_{t}+\varepsilon_{i, t}
$$

where, MurderRates ${ }_{i, t}$ is the murder rate per one hundred thousand inhabitants in province $i$ at time $t$; AsylumSeekers $s_{i, t}$ is the stock of asylum seekers in province $i$ per 100 inhabitants; Controls $_{i, t}$ is a vector containing all control variables, which includes Male Population, Young Population, Young Male, Income Proxy and Prisoners as described in Section 3.4; $\zeta_{i}$ are the timeinvariant fixed effects; $\theta_{t}$ are the year fixed effects which capture annual shocks common to all the provinces while $\varepsilon_{i, t}$ are the residuals, clustered at the provincial level.

The OLS estimated results for Equation 1 are shown in Table 4. We estimate three separate regressions for three periods: 2000-2012 (column 1), 1997-2010 (column 2) and 1997-2012 (column 3). Our preferred specification refers to the period 2000-2012 because it is during this time that Colombians began to seek asylum in Ecuador. Another reason is that it is important to include a variable of deterrence when determining the factors driving the violent crimes. In our case, we use Prisoners as a deterrent variable and this information is only available from 2000 onwards. On the other hand, the choice of the period 1997-2010 in column 2 is due to the fact that this is the reference period for the "Conflict Spillover."

The results from Table 4 indicate that Asylum Seekers is negative and significant effect on the muerder rate in the regression represented by columns (1) and (2), whereas it is not in the third specification. From column (1), an increase by factor of 1 in the asylum seekers measurement, is associated with a decrease of approximately one homicide per 100,000 inhabitants per year. From specifications (1) and (2), we see that all control variables are not statistically significant, but with similar signs to the ones predicted by the literature, except for Density. In (3) Male Population, 
Young Population and Young Male are significant . As expected, provinces which are younger and with more male have higher murder rates. Interestingly, the interaction term is negative, which suggests substitution effects.

\section{[Table 4 ABOUT HERE]}

\subsubsection{Asylum Seekers Spillover - Instrumental Variable}

There are reasons to suspect that our measure of asylum seekers is endogenous. This happens because of the presence of unobserved time-varying variables which can both affect the decision to leave the country and crime levels. Furthermore, Bell et al. (2013) suggested that, if immigrants decide to move to areas which are experiencing a decline in crime, this would also bias downward the coefficient. We solve the endogeneity problem by instrumenting Asylum Seekers in a similar fashion as Angrist and Kugler (2003) that considered migration from former Yugoslavia. ${ }^{31}$ We construct our instrument combining a national time series part and a cross sectional one. We define this instrument as:

$$
\text { AsylumInstrument }_{i, t}=\frac{1}{\text { Avg Distance }_{i}} \times \text { Anti Coca Strategy }_{t}
$$

where Avg Distance, the cross section dimension, is the average distance to the three borders, one for each province, in kilometers. Provinces which are closer to the Colombian borders are likely to attract more asylum seekers given their proximity to the home country. We preferred to use the inverse measure in order to have the same sign in the cross section and time series component of the instrument. ${ }^{32}$ The time series dimensions, Anti Coca Strategy depends on the fact that most of the displaced people were living in rural areas where the cultivation of coca leaves was predominant as were subjected to areal fumigation and manual eradication as a consequence

\footnotetext{
${ }^{31}$ A very similar instrument to the one we propose has been employed by (Calderón-Mejía and Ibáñez, 2016) to evaluate the impact of Colombian internal displacement, due to the violence of the conflict, on to various outcome in the local labor market.

${ }^{32}$ Calderón-Mejía and Ibáñez's instrument was calculated as the sum of the cumulative number of massacres divided by the inverse of the distance from the city to the place of the massacre.
} 
of the implementation of the Plan Colombia. ${ }^{33}$ We consider the sum of hectares of these two activities weighted by the total number of hectares cultivated with coca leaves (ODC, 2013). We calculate this measure for all the Colombian municipalities but the bordering ones. As a robustness, we also consider such measure only for the farthest province in Colombia, La Guajira, in the far north of Colombia since cultivation patterns might be correlated among different regions in Colombia. However, given the extreme geographical distance it should be completely exogenous to the structural equation. Finally, we also consider the cultivation of coca leaves in the entire country of Colombia. Consequently, we define the two stage least square model as follows:

$$
\text { MurderRates }_{i, t}=\beta \text { AsylumSeeekers }{ }_{i, t}+\alpha \text { Controls }_{i, t}+\zeta_{i}+\theta_{t}+\varepsilon_{i, t}
$$

The regression results for the Two-Stage least squares (2SLS) are presented in Table 5. The coefficients of the first stage are always positive and highly significant. These results indicate that asylum seekers are more likely to go to provinces closer to the border and when the 'anti-coca cultivation' strategies are more incisive. Moreover, the explanatory power for all regressions is significant in all the specifications with R-squared values ranging from 0.453 to 0.565 . For all specifications, the Kleinbergen-Paap F-Statistics(Kleibergen and Paap, 2006) are higher than the rule of thumb value of 10, as suggested by Stock and Yogo (2005), except for specifications (4) and (5), with this last one being 9.7 . The second stage results show that the coefficient is always negative and significant for four of the six specifications. If we consider column (2), we see that an increase of the stock of asylum seekers by 1 unit, about the double of the mean, there is a decrease by approximately 2 homicides per one hundred thousand inhabitants per year. These results are in line with similar studies found elsewhere in the literature. For example, Bell et al. (2013) do not find a positive effect of their migration measurement on measures of violence. In summary, our regression analysis does not provide evidence that the influx of Asylum seekers into Ecuador has

\footnotetext{
${ }^{33}$ For an interesting discussion on the factors that force people to migrate, please refer to Palacios (2012).
} 
contributed to the increase in the incidence of violent crimes in Ecuador.

[Table 5 ABOUT HERE]

\subsection{Conflict Spillover: The Presence of Armed Groups on Violence}

We also want to investigate if the presence of Colombian armed guerrilla groups (i.e. the Conflict Spillover) near the border had a significant effect on the incidence of violent crimes in Ecuador's bordering provinces. In particular, we want to investigate the extent to which higher violence, as a consequence of the armed conflict, in the Colombian bordering municipalities translates into higher violence in bordering provinces of Ecuador. For this analysis we estimate the following model:

$$
\text { MurderRates }_{i, t}=\beta \text { BordFarc }_{i, t}+\alpha \text { Controls }_{i, t}+\zeta_{i}+\theta_{t}+\varepsilon_{i, t}
$$

where MurderRates ${ }_{i, t}$ is the murder rate as defined in Section 4.1; BordFarc $_{i, t}$ is equal to the sum of all the FARC related conflict indicators for the Colombian municipalities that share a border with Ecuador, weighted by the municipality population (i.e $F A R C$ event rate $_{i, t}$ ) for each of the three bordering provinces (i.e., Esmeraldas, Carchi and Sucumbios) and zero for all others; Controls $_{i, t}, \zeta_{i}$ and $\theta_{t}$ are the same as defined in Section $4.1 ; \varepsilon_{i, t}$ is a cluster-robust standard error at the provincial level.

In Table 6 we show the empirical results after estimating Equation 4. Conditional on the data availability, we estimate six specifications using different measurements of border conflict, all the control variables earlier defined from 1997 to $2010 .{ }^{34}$ The first specification, Column (1) in Table 6, is that described by Equation 4. Even though the coefficient for FARC event rate has the expected positive sign (i.e. higher conflict in Colombia is associated with higher violent crimes in Ecuadorean bordering provinces), its magnitude is not statistically different from zero. Thus, we fail to reject the hypothesis that the exposure to the Colombian conflict in the northern Ecuadorean

\footnotetext{
${ }^{34}$ For all these specification we do not include the Income Proxy because it starts from 2000, but we use it in later estimations.
} 
provinces is related to the level of violence in these Colombian municipalities. Nevertheless, from a practical point of view, we can discuss the magnitude impact of the estimated coefficient. An increase by one unit of Bord Farc would lead to an increase in murder rates by 0.014 or $0.1 \%$ in the Ecuadorean bordering provinces, a negligent effect. From columns (2)-(6) we present the results of the same regression using alternative measurements of border conflict. In all these cases we also fail to reject the hypothesis that the exposure to the Colombian conflict in the northern Ecuadorean provinces is related to their level of violence. ${ }^{35}$

\section{[Table 6 ABOUT HERE]}

In Table 7 and Table 8 we present some robustness check in an effort to determine the sensitivity of these results to alternative specifications. In column (1) and (2) from Table 7, we assume that the spillover effects are not confined to the three bordering provinces but that are gradually felt throughout the country at a decreasing intensity the farther from the border we move. In order

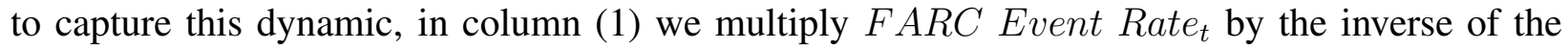
average distance to one of the three borders. In column (2) we multiply by the log of the inverse of the distance to give more weights to provinces close to the border. Following the same reasoning, in column (3) and (4) we extend the 'treated' units to Orellana and Imbabura, which are also close to the border. In column (5) we also add many conflict variables which cannot be ascribed to guerrilla members but might represent the intensity of conflict as well. In column (6), we consider up to the year 2008, rather than 2010. As we mentioned in Section 2, 2008 was a key year as the Ecuadorean government acknowledged the presence of security issues in the northern country. As a consequence, the government started increasing the presence of Ecuadorean army close to the border. Finally, in column (7), we consider the level of conflict in the whole Colombia, and not only in the bordering provinces. In summary, from all the different specifications we have presented, we find no evidence that violence derived from the armed conflict in Colombia is related to the incidence of violence in the bordering provinces of Ecuador.

\footnotetext{
${ }^{35}$ The definitions and sources for alternative measurements of border conflict can be found in Table 2.
} 


\section{[Table 7 and Table 8 ABOUT HERE]}

In Table 8, we perform additional robustness checks. In the first column, we add the variables Income Proxy and Prisoners, which are available from 2000. In column (2), we estimate the same regression as in column (1) of Table 6 but with random effects, rather than fixed effects, which is a feasible GLS. In column (3) we address the econometric issue known as "few clusters"(Cameron and Miller, 2015). ${ }^{36}$ We address this issue by using wild cluster bootstrap with asymptotic refinement. ${ }^{37}$ In all these three specifications, we never find significant effects. Another concern could be that the relationship is not contemporaneous as it might take time to incubate violence in the northern Ecuadorean provinces. In order to verify whether this is the case we consider how lags, up to three, affect homicide rates. In columns (4)-(6) we report this exercise only for the variable Bord Farc. In columns (4) and (5) we only include the first and second lags respectively, in addition to the contemporaneous effect of Bord Farc. In these cases, the lag coefficients and the contemporaneous effect are never significant. Nevertheless, when we include the two lags and the contemporaneous effect as in column (6), the coefficient of interest becomes statistically significant and negative. One explanation for this results is that regression analysis still suffers from serial autocorrelations despite we clustered the standard errors at the provincial level. In light of these results, we also estimate the model using first differences, which is more robust the fixed effects and auto correlation, in effort to discard any possible misspecification of the regressions. In any of these estimation we are able to find evidence of a significant conflict spillover in Ecuador's bordering provinces.

\subsubsection{Conflict Spillover - Instrumental Variable}

The OLS analysis showed that exposure to the Colombian conflict did not lead to significant changes of the level of conflict in the northern Ecuadorean provinces. However, our explanatory variable, Bord Farc $_{i, t}$, might not be completely exogenous. Rather than reverse causality, we are

\footnotetext{
${ }^{36}$ As the authors explain, having few clusters lead to over-rejection and confidence intervals that are too narrow.

${ }^{37}$ We also considered other types of bootstrapping which gave similar results but we did not report to save space. These results are available upon request.
} 
concerned with the presence of omitted variables and measurement errors. We might think of some variables that affect either the exposure to conflict and the level of crime, such as institutional factors or socio-economic ones. Measurement errors could also be an issue, either for the dependent and explanatory variable. Therefore, we use an instrumental variable approach, and as instrument, we consider the conflict events happening in the farthest province in Colombia, La Guajira, in the far north of Colombia. The idea is that the intensity of conflict in the north of Colombia is linked to the one in southern Colombia because the illegal groups are somehow connected. However, given the extreme geographical distance it should be completely exogenous to the structural equation. Then we multiply the inverse of the average distance from this region to each of the Ecuadorean one, as we previously explained. Specifically, we define the instrument is defined as:

$$
\text { ConflictInstrument }_{i, t}=\frac{1}{\text { Distance }_{i, j}} \times{\text { Conflict } \text { Measure }_{j, t}}
$$

In Table 9 we show the results from the 2SLS regression analysis. As before, we estimate different specifications to account for the sensitivity of the results and used the same control variables as before from 1997 to $2010 .{ }^{38}$ From Table 9, we see that all instruments are significant and the Kleibergen-Paap F-Statistics are approximately 8 in all specifications. These results confirm those previously presented where we have concluded that the Conflict Spillover has not affected the violent crime rates in the bordering provinces of Ecuador.

\section{[Table 9 ABOUT HERE]}

\section{Conclusions}

This work analyzes the impact of two spillover effects of the Colombian conflict on the violence levels in Ecuador. The first effect, the "Asylum Seekers Spillover", deals with the arrival of asylum seekers. As a result of the implementation of the Plan Colombia, the Colombian armed

\footnotetext{
${ }^{38}$ In these specifications we did not include the income proxy due to data availability and our interest of using data from 1997.
} 
conflict intensified and caused hundred of thousands of Colombians to be displaced. Consequently, Colombians sought refuge in Ecuador in large numbers for an extended period of time and as a result of the influx of Colombian refugees, they were blamed for the increasing violent crimes in Ecuador's bordering provinces. The latter, the "Conflict Spillover" effect, addresses the relationship between the increasing illegal drug activities by Colombian armed groups in the bordering provinces of Ecuador and the incidence of violent crimes in the region. Meanwhile, the implementation of the Plan Colombia and therefore the intensification of the conflict the illegal organizations sought after new routes to resupply for arms and ammunitions as well as to transport and distribute the drugs out of Colombia through Ecuador. Thus, Ecuadorean bordering provinces with Colombia experienced a spike in the illegal trades of drugs and incursions by these illegal groups. As a result, this new dynamic in the region was also blamed for the increasing violence in Ecuador's bordering provinces. In summary, both the presence of the Colombian asylum seekers and the combination of illegal groups using Ecuador as a safekeeping place and transporting drugs was perceived by the state and public opinion as the reason for the increased levels of violence in the bordering provinces.

Despite the public relevance of these issues, there exists no empirical evidence that can attest any of these areas of concern. For this, we build an innovative panel data at the Ecuadorean provincial level for the period 1997 to 2012. For our empirical analysis, we use a Two-Stage least squares approach in order to address the likely endogeneity nature of the asylum seekers variable. As instrument, we consider the inverse of the average distance of each province from the three borders multiplied by various measures of the intensity of areal and manual fumigation. The reason behind implementing this instrument is that, as the Plan Colombia intensified, more and more people migrated to escape violence. These people moved preferably closer to the border. Our analysis does not find any evidence between the arrival of asylum seekers and the incidence of violent crimes in the Ecuadorean bordering provinces. On the contrary, although marginally, our estimates suggest that the stock of asylum seekers leads to a reduction of homicide rates in these provinces. The results are robust across all the specifications. Our results are in line with those by 
Bell et al. (2013), which did not find a positive effect between migration and violent crimes.

On the other hand, the "Conflict Spillover" attempts to link the presence of illegal groups, and drug activities, in Ecuador's bordering provinces. In this case, and due to the data limitations, we construct an indirect measure of the presence of these activities in Ecuador. Concretely, we use the intensity of conflict in the Southern Colombian municipalities as a proxy for the increasing presence of armed groups and their illegal activities in the Ecuadorean bordering provinces. Our premise is that as the conflict in Colombia intensifies, guerrilla groups are forced to seek alternative channels to resupply and distribute the drugs outside Colombia. As a measure of the intensity of the conflict we consider a series of indicators of the presence of FARC and other illegal groups. In our estimations we recognize the data constraints and consequently employed different econometric techniques, use alternative time frames and measures of conflict in order to cope with these limitations. Our results indicate that the Ecuadorean provinces which received this spillover effect did not experience an increase in the homicide rates significantly different from the other provinces. These findings are robust to numerous specifications such as different definition of treated units and treatment variables.

These results show that the presence and operation of armed groups in the region did not necessarily lead to an increase in violence. One possibility, which we have previously documented, is that Ecuador has been used as a transit point for the distribution of drugs. Consequently, it is possible that the illegal groups in northern Ecuador operated in a 'quiet' way without recurring to high levels of violence. There are many examples of organized criminal groups that operate in such a way: for example Mexico's drug cartels before the crime boom of the last years (Castillo et al., 2012). However, this situation can change quickly and homicide rates might spike as a result. Another possible explanation is that it needs time to 'incubate' criminal capital in these provinces and violence will increase only after some years. Although, in this case it does not seem to be the case given that we have analyzed the issue for over a decade.

Another aspect to consider is that the guerrillas were not offered the protection in Ecuador as Martinez (2017) claims they did in Venezuela under the presidency of Hugo Chávez. If this was 
the case, it might explain the guerrillas keeping a low profile in the Ecuadorian region in order to be able to operate without any disturbance. Additionally, even though we have made efforts to collect data from various sources to conduct our study, data availability has been a significant hurdle to overcome. We do not believe our conclusions to be definite, but we hope to begin a reacher discussion on this topic which has not been explored thus far in the literature.

Nevertheless, our results have important policy implications to be considered in the context of Ecuador and other regions with similar circumstances. It is evident that there was a pervasive fear of refugee-related violent crime on display by both the Ecuadorean public-opinion and politicians alike. However, from our analysis, it appears that this fear was unfounded as the influx of asylum seekers appears not to be associated with the violent crime rate in any of these provinces. The low incarceration rate among Colombian citizens with refugee status appears to also validate this conclusion (only 108 or $0.2 \%$ incarcerated of the total refugee population).

There exist other forms of violent and non-violent crimes (e.g. petty crimes, sexual offense, extortion and kidnapping) for which asylum seekers were blamed for in Ecuador. However, there exists very few evidence indicating a wide spread trend. On the contrary, these appear to be isolated events which gathered great attention by the press and public. These reports, created an imbalance between the documented crimes and crime rumors, which fueled the negative perception against asylum seekers. In this sense, the Ecuadorean authorities failed to distinguish that asylum seekers, running away from the most violent civil war in the continent, do not necessarily bring the violence over with them. On the contrary, it creates a hostile environment between the local population and the already vulnerable asylum seekers. Therefore, it is important that the authorities rely in factual evidence to minimize any hostility against the vulnerable population and to be able to effectively allocate resources and target the factors driving crime rates in these regions.

There are also other dimensions through which the intensification of the Colombian conflict may have affected the bordering provinces of Ecuador. These factors vary from economic to social aspects and other forms of crime that we have not considered in our work. For example, increasing unemployment rate, strain in social and governmental services as well as other forms of violent and 
non-violent crimes not explored in our study. These are also spillovers from the conflict that need to be studied using alternative and more disaggregated level datasets. These are also important areas of research and we encourage the exploration in future work. 


\section{Bibliography}

Acemoglu, D., J. Robinson And R. SAntos, "The monopoly of violence: Evidence from Colombia," Working Paper 15578, NBER, December 2013.

ACNUR, “Ecuador," Online (April 2011), Acceessed on April 2017.

— , "El ACNUR en Ecuador," (2015), Accessed on April 10, 2017.

Angrist, J. D. And A. D. Kugler, "Protective or counter-productive? labour market institutions and the effect of immigration on eu natives," Economic Journal 113 (2003), 302-331.

BeitTel, J. S., "Colombia: Background, U.S. Relations, and Congressional Interest," CRS Report for Congress RL32250, Congressional Research Service, November 2011.

Bell, B., F. FASANI AND S. MACHIn, "Crime and Immigration: Evidence from Large Immigrant Waves," The Review of Economics and Statistics 95 (October 2013), 1278-1290.

Bourguignon, F., J. N. NeZ And F. SAnchez, "A Structural Model of Crime and Inequality in Colombia," Journal of the European Economic Association 1 (04/05 2003), 440-449.

CALDERÓN-MejíA, V. AND A. M. IBÁÑEZ, "Labour market effects of migration-related supply shocks: evidence from internal refugees in Colombia," Journal of Economic Geography 16 (September 2016), 695-713.

Camacho, A. And C. Rodriguez, "Firm Exit and Armed Conflict in Colombia," Journal of Conflict Resolution 57 (February 2013), 89-116.

Cameron, A. C. And D. L. Miller, “A Practitioner's Guide to Cluster-Robust Inference,” The Journal of Human Resources 50 (2015), 317-373.

Castillo, J., M. D. D. And R. P., "Illegal drug markets and violence in Mexico: The causes beyond Calderón,” Technical Report, Working paper, Universidad de los Andes., 2012.

Centro de Memoria Histórica, "Estadísticas del conflicto armado en Colombia," http://www.centrodememoriahistorica.gov.co/micrositios/informeGeneral/basesDatos.html (2017).

CODHES, “Estadísticasticas Históricas De Desplazamiento,” Online (2012).

Couttenier, M., V. Preotu, D. Rohner and M. Thoenig, "The Violent Legacy of Victimization: Post-Conflict Evidence on Asylum Seekers, Crimes and Public Policy in Switzerland," CEPR Discussion Papers 11079, C.E.P.R. Discussion Papers, January 2016 a.

— - "The Violent Legacy of Victimization: Post-Conflict Evidence on Asylum Seekers, Crimes and Public Policy in Switzerland," CEPR Discussion Papers 11079, C.E.P.R. Discussion Papers, Jan $2016 b$.

DAZA, N. AND M. RodRíGuez, "Determinants of Civil Conflict in Colombia: How Robust are they?," Defence and Peace Economics 23 (April 2012), 109-131. 
DeAs, M., The Farc Files: Venezuela, Ecuador and the Secret Archive of 'Raúl Reyes' (The International Institute for Strategic Studies, 2011).

Dell, M., “Trafficking Networks and the Mexican Drug War," American Economic Review 105 (June 2015), 1738-79.

DiX-Carneiro, R., R. R. Soares And G. Ulyssea, "Local Labor Market Conditions and Crime: Evidence from the Brazilian Trade Liberalization," Iza discussion papers, Institute for the Study of Labor (IZA), 2016.

El Comercio, "Las Águilas Negras atraviesan la frontera y llegan hasta Quinindé," http://www.elcomercio.com/actualidad/seguridad/aguilas-negras-atraviesan-frontera-y.htmline (July 2010a), accessed on November 2, 2016.

"No todo extranjero provoca inseguridad," http://www.elcomercio.com/actualidad/seguridad/noextranjero-provoca-inseguridad.html (December 2010b), accessed on November 2, 2016.

- "Tres sectores se abastecen del tráfico de armas," http://www.elcomercio.com/actualidad/seguridad/tres-sectores-se-abastecen-del.html (2015), accessed on November 2, 2016.

El EsPeCtAdoR, "Desmovilizados de las Farc agravan violencia en Ecuador," http://www.elespectador.com/noticias/judicial/desmovilizados-de-farc-agravan-violenciaecuador-articulo-231410 (October 2010a), accessed on November 2, 2016.

- "Farc tienen 1500 hombres en 28 campamentos en Venezuela," http://www.elespectador.com/noticias/judicial/farc-tienen-1500-hombres-28-campamentosvenezuela-articulo-213492 (July 2010b), accessed on November 2, 2016.

El Nuevo DiARIO, "FARC tiene campamentos en Ecuador," http://www.elnuevodiario.com.ni/internacionales/10540-farc-tiene-campamentos-ecuador/ (March 2008), accessed on November 2, 2016.

El Tiempo, "El Conflict Armado Superó las Fronteras," http://www.eltiempo.com/archivo/documento/MAM-867462 (February 1999), accessed on November 2, 2016.

EL UNIVERSO, "Delincuentes se mimetizan entre los miles de refugiados," http://www.eluniverso.com/2010/12/19/1/1447/delincuentes-mimetizan-miles-refugiados.html (Diciembre 2010), accessed on November 2, 2016.

- "Capturan en Sucumbíos a presunto cabecilla de las FARC," http://www.eluniverso.com/noticias/2016/01/23/nota/5362621/capturan-sucumbios-presuntocabecilla-farc (January 2016), accessed on November 2, 2016.

FAjnzylber, P., D. Lederman And N. LoAyza, "Inequality and Violent Crime," The Journal of Law and Economics 45 (2002a), 1-39.

“What causes violent crime?," European Economic Review 46 (July 2002b), 1323-1357. 
FES, "Relaciones Colombia-Ecuador: retos y oportunidades para el restablecimiento de la confianza," Policy Paper 11, Friedrich-Ebert-Stiftung (FES), December 2006, language: Spanish.

FGE, "Delitoscopio Informe Estadístico," Technical Report, Fiscalía General del Estado - Ecuador, Avs. Patria s/n y 12 de octubre. Edif. Patria, December 2014, in Spanish.

Gerson, J. And V. Perez, "Plan Colombia?s Onset: Effects on Homicides and Violent Deaths," Borradores de Economia 746, Banco de la Republica de Colombia, December 2012.

Guyton, K., D. Loomis, Y. Grosse, F. El Ghissassi, L. Benbrahim-TallaA, N. Guha, C. Scoccianti, H. MATTOCK AND K. Straif, "Carcinogenicity of tetrachlorvinphos, parathion, malathion, diazinon, and glyphosate," The Lancet Oncology 16 (May 2015), 490_ 491.

IbÁÑEZ, A. M. AND C. E. VÉLEZ, "Civil Conflict and Forced Migration: The Micro Determinants and Welfare Losses of Displacement in Colombia," World Development 36 (April 2008), 659-676.

INEC, "Anuario de Estadística de Transporte," http://www.ecuadorencifras.gob.ec/anuarios-detransporte-2/ (2017a), accessed multiple occasions.

“Anuario de Nacimientos y Defunciones," http://www.ecuadorencifras.gob.ec/anuario-denacimientos-y-defunciones/ (2017b), accessed multiple occasions.

_ "Población y Demografía," http://www.ecuadorencifras.gob.ec/censo-de-poblacion-yvivienda/ (2017c), accessed multiple occasions.

KLEIBERGEN, F. AND R. PAAP, "Generalized reduced rank tests using the singular value decomposition,” Journal of Econometrics 133 (2006), 97 - 126.

LevitT, S. D., "The Effect of Prison Population Size on Crime Rates: Evidence from Prison Overcrowding Litigation,” The Quarterly Journal of Economics 111 (1996), 319-351.

MARTINEZ, L. R., “Transnational Insurgents: Evidence from Colombia's FARC at the border with Chávez's Venezuela,’ Journal of Development Economics 126 (2017), 138-153.

MEJIA, D. AND E. PoSADA, “Cocaine production and trafficking: what do we know?," Working Paper 4618, The World Bank Research, 2008.

Mejia, D. And P. Restrepo, "Bushes and Bullets: Illegal Cocaine Markets and Violence in Colombia," Documento CEDE 2013-53, Universidad de los Andes Department of Economics Research Paper Series, 2013.

Mejia, D., P. Restrepo And S. V. Rozo, "On the Effects of Enforcement on Illegal Markets: Evidence from a Quasi-experiment in Colombia," Policy Research Working Paper WPS7409, The World Bank, 2015.

Miguel, E., S. M. Saiegh And S. Satyanath, "Civil War Exposure And Violence," Economics and Politics 23 (03 2011), 59-73. 
MorAleS, J. S., "The Impact of Internal Displacement on Destination Communities: Evidence from the Colombian Conflict," HiCN Working Papers 209, Households in Conflict Network, February 2016.

ODC, "Reporte de Drogas de Colombia," Technical Report, Ministerio de Justicia y del Derecho - Observatorio de Drogas de Colombia, 2013.

OSPINA, O. R. AND L. SANTACRUZ, "Refugiados urbanos en Ecuador: estudio sobre los procesos de inserción urbana de la poblaciónn colombiana refugiada, el caso de Quito y Guayaquil," http://www.flacsoandes.edu.ec/libros/125120-opac (2011).

PAlacios, P., "Forced Displacement: Legal Versus Illegal Crops," Defence and Peace Economics 23 (April 2012), 133-160.

REYES, L. C., "Estimating the Causal Effect of Forced Eradication on Coca Cultivation in Colombian Municipalities," World Development 61 (September 2014), 70-84.

SoARES, R. R., "Crime Reporting as a Measure of Institutional Development," Economic Development and Cultural Change 52 (July 2004a), 851-871.

—- "Development, crime and punishment: accounting for the international differences in crime rates," Journal of Development Economics 73 (2004b), 155-184.

SoAres, R. R. And J. NARitomi, "Understanding High Crime Rates in Latin America: The Role of Social and Policy Factors," in The Economics of Crime: Lessons for and from Latin AmericaNBER Chapters (National Bureau of Economic Research, Inc, 2010), 19-55.

Stock, J. And M. Yogo, Testing for Weak Instruments in Linear IV Regression, chapter 5 (New York: Cambridge University Press, 2005), 80-108.

ThE GUARDiAn, "Colombia's armed groups sow seeds of new conflict as war with Farc ends," https://www.theguardian.com/world/2017/apr/18/colombia-farc-rebels-armed-groups (April 2017), accessed on April 17, 2017.

UNHCR, "UNHCR Statistics," http://popstats.unhcr.org/en/overview (April 2017), accessed on multiple ocassions.

United States Department of State, "United States Department of State," http://www.refworld.org/docid/4c63b6492d.html (August 2010), accessed 15 April 2017.

UNODC, "Drug trafficking statistics," Online (April 2017).

USG, "U.S. Foreign Assistance Performance Publication - Fiscal Year 2009," https://20092017.state.gov/documents/organization/159260.pdf (2009).

Youngers, C. A., Drugs and Democracy in Latin America: The Impact Of U.S. Policy (Lynne Rienner Publishers, 2004). 


\section{Appendix Figures}

Figure 1: Number of Asylum Seekers and Refugees in Ecuador for the period 1997-2012

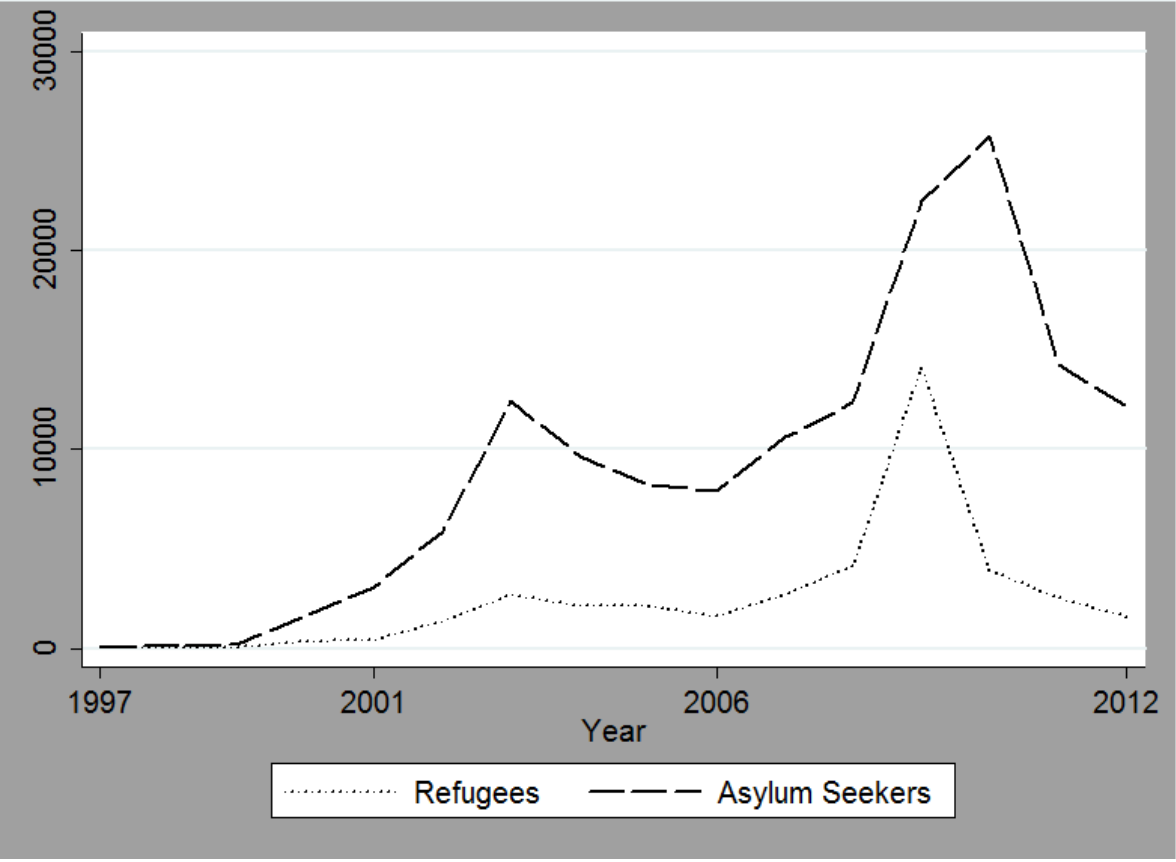

This figure represents the number of people seeking asylum and refugees in Colombia per year. Source: Ecuadorean Ministry of Foreign Affairs. 
Figure 2: Evolution of Asylum Seekers for the period 1997-2012.

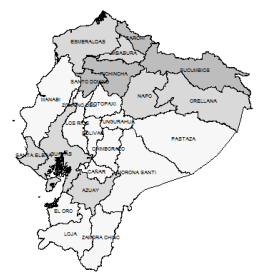

1997

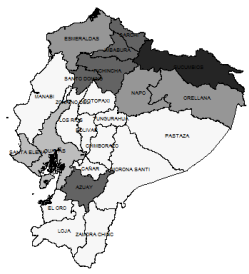

2006

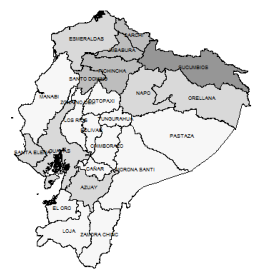

2000

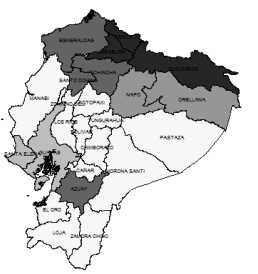

2009
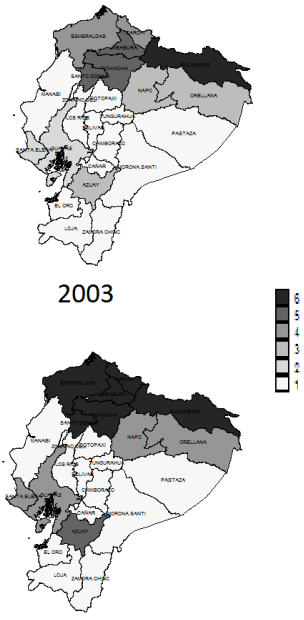

2012

This figure represents the evolution of Asylum Seekers over the years in the Ecuadorean provinces. The categories represents the 6 percentiles calculated by pooling all the years together. Specifically, we have:Category $1: 0$, Category 2: 0-0.0062218, Category 3: 0.0062218-0.0750423, Category 4:0.0750423-0.5353671, Category 5: 0.5353671-01.95366, Category 6:bigger 1.95366.. We include all the current 23 provinces, excluding Galapagos. New provinces have the same values as the one from which they separated (Santa Elena and Pichincha for example).

Figure 3: Asylum Seekers by Country of Origin in Ecuador (2000-2012)

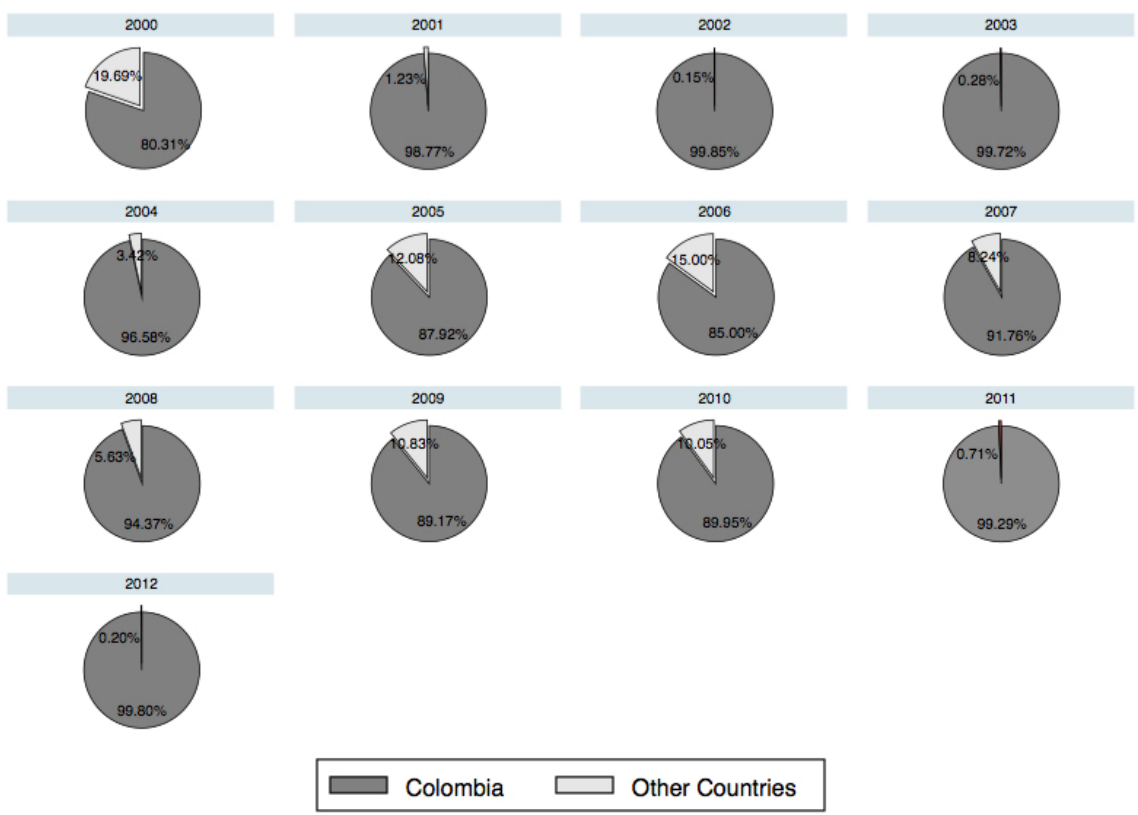

Source: UNHCR (2017). 
Figure 4: FARC events rate and cocaine seizure in Ecuador

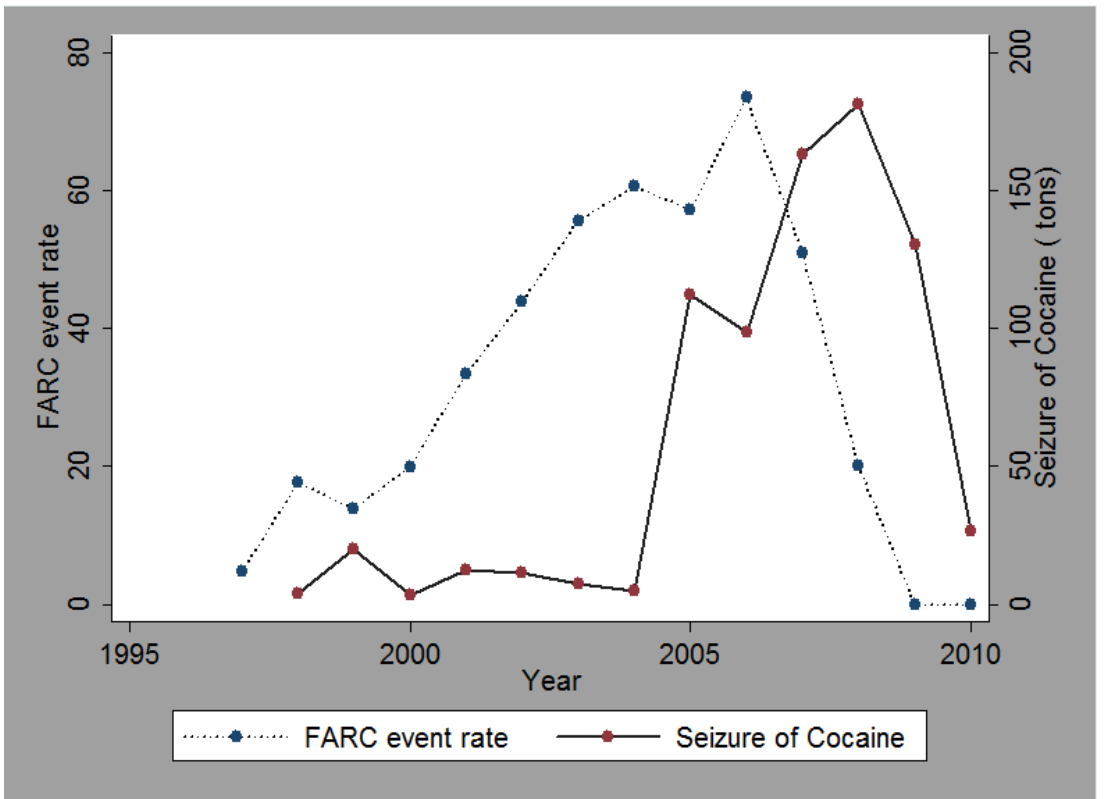

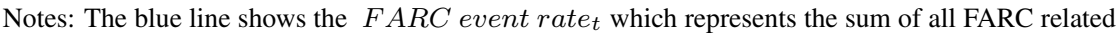
conflict events in the Colombian bordering municipalities with Ecuador, weighted by population. The red line shows the tons of cocaine seized in Ecuador. Data Source: The data for 'Cocaine Seizure' has been collected from the 'Drug trafficking statistics' database and the authors own calculations (UNODC, 2017). 
Figure 5: Explaining the identification strategy for the Spillover 2

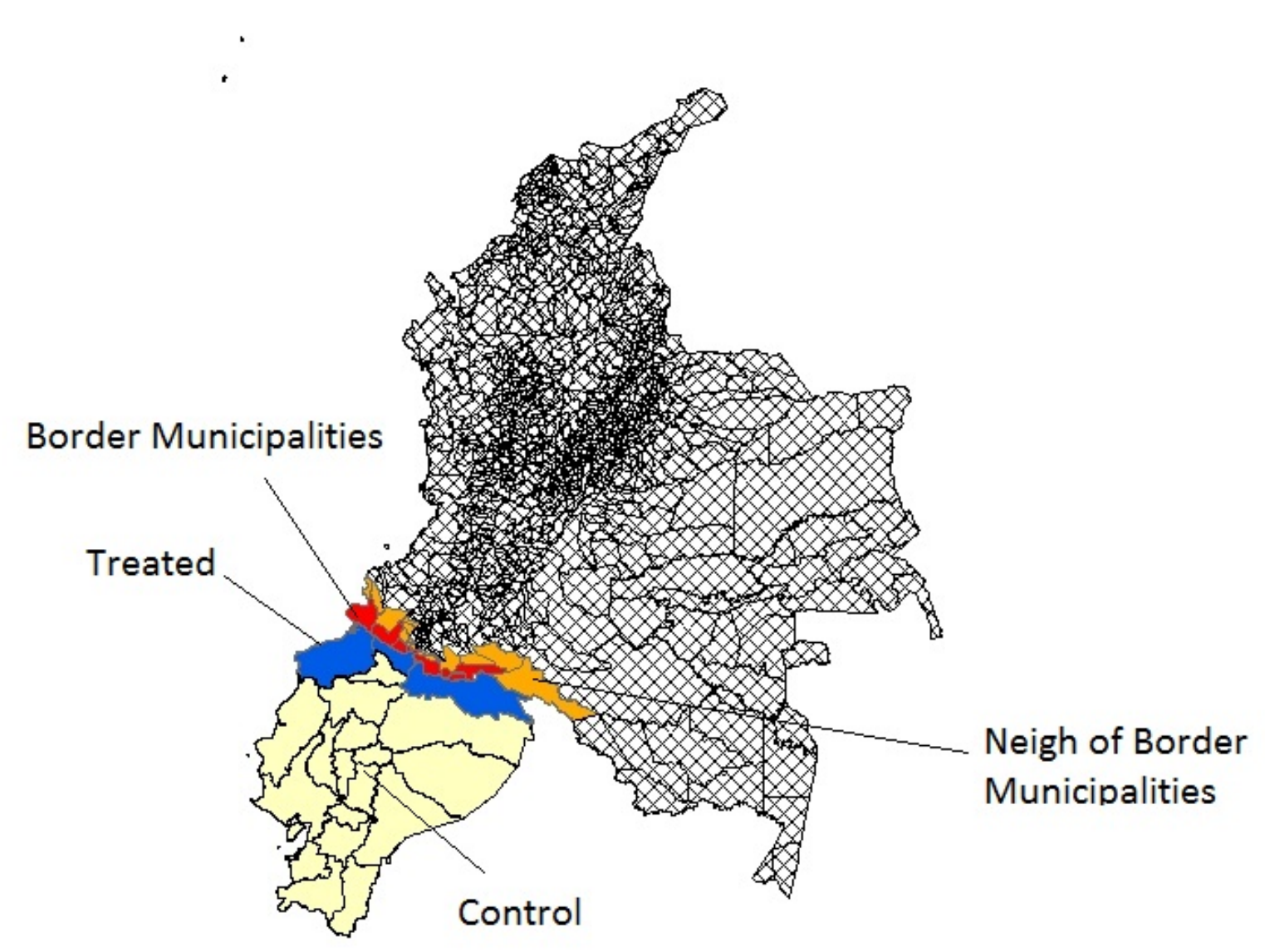

Notes: This maps shows Ecuadorean provinces and Colombian municipalities. The blue provinces are the ones at the border and represent the "treated" in the baseline specification. The red Colombian municipalities are the ones at the border from which we have calculated the "FARC event rate" measure. The orange municipalities are the neighbors of the "red ones". 
Figure 6: FARC events rate and Homicides rates in bordering vs not bordering provinces

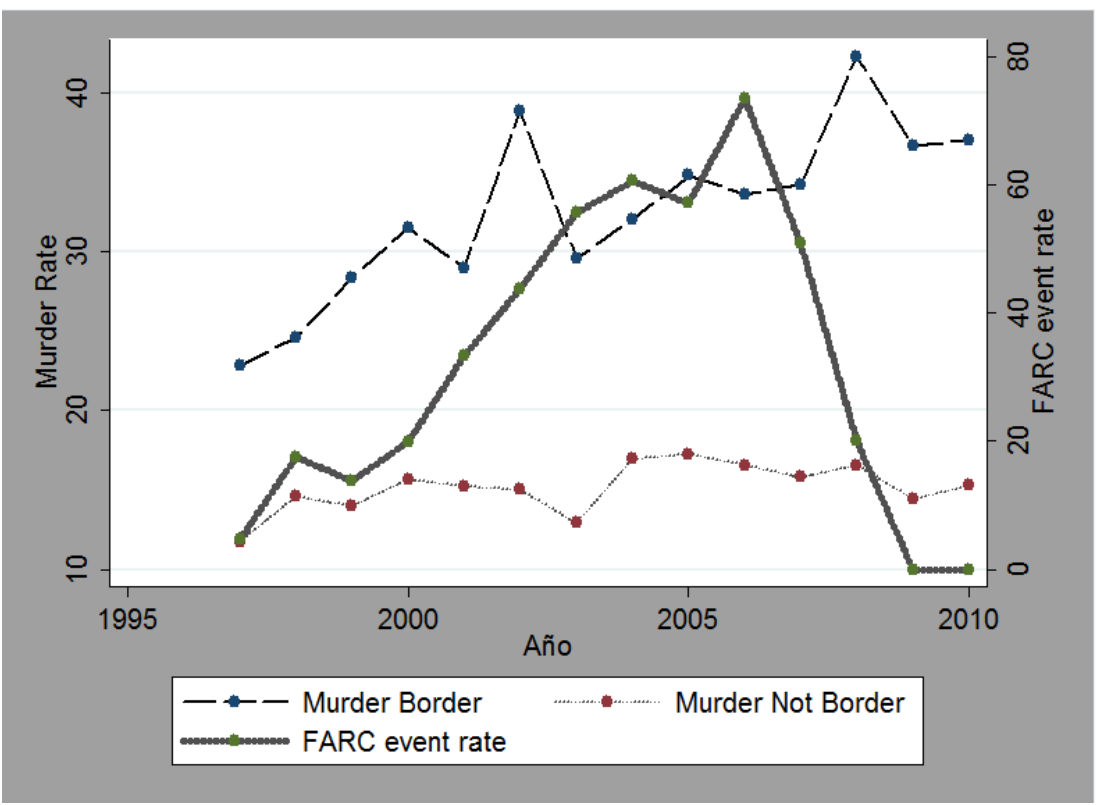

Notes: The graph compares the evolution of homicide rates in the three bordering provinces with Colombia and in the rest of the provinces with FARC event rate.Table 2 explain how we constructed such variable. 


\section{Appendix Tables}

Table 1: Summary Statistics

\begin{tabular}{lrrrrr}
\hline Variable & $N$ & Mean & Std.Dev. & Min. & \multicolumn{1}{c}{ Max. } \\
\hline Murder & 320 & 13.05 & 11.20 & 0.00 & 67.26 \\
Asylum Seekers & 320 & 0.52 & 1.71 & 0.00 & 13.83 \\
Bord FARC & 320 & 4.25 & 13.86 & 0.00 & 73.40 \\
FARC event rate & 320 & 28.31 & 24.42 & 0.00 & 73.40 \\
Bord FARC Nei & 320 & 3.80 & 12.56 & 0.00 & 64.56 \\
FARC Nei event rate & 320 & 25.34 & 22.45 & 0.00 & 64.56 \\
Bord All & 320 & 4.95 & 15.85 & 0.00 & 78.45 \\
All event rate & 320 & 33.00 & 27.30 & 0.00 & 78.45 \\
Bord All Nei & 320 & 4.54 & 14.64 & 0.00 & 69.78 \\
All Nei event rate & 320 & 30.25 & 25.45 & 0.00 & 69.78 \\
Bord FARC Het & 320 & 11.03 & 36.22 & 0.00 & 191.17 \\
FARC Het event rate & 320 & 73.52 & 64.33 & 0.00 & 191.17 \\
Bord All Het & 320 & 8.96 & 28.62 & 0.00 & 136.87 \\
All Het event rate & 320 & 59.71 & 49.20 & 0.00 & 136.87 \\
Bord FARC Inv & 320 & 0.07 & 0.08 & 0.00 & 0.44 \\
Bord FARC Nei Inv & 320 & 0.06 & 0.07 & 0.00 & 0.39 \\
Density & 320 & 67.95 & 56.05 & 1.94 & 245.80 \\
Male Population & 320 & 50.30 & 2.11 & 45.50 & 56.05 \\
Young Population & 320 & 27.09 & 1.90 & 12.62 & 31.90 \\
Young Male & 320 & 1364.13 & 128.02 & 622.30 & 1722.19 \\
Income Proxy & 320 & 549.63 & 495.96 & 0.972488 .74 \\
Prisoners & 260 & 1.76 & 0.94 & 0.35 & 7.27 \\
\hline \hline Instrument Table 5, col. 1,4,5 320 & 0.00 & 0.00 & 0.00 & 0.01 \\
Instrument Table 5, col. 2 & 320 & 246.82 & 175.45 & 45.92 & 1034.28 \\
Instrument Table 5, col. 3 & 320 & 0.60 & 0.43 & 0.00 & 2.24 \\
Instrument Table 9 & 320 & 326.05 & 239.60 & 45.01 & 1376.99 \\
\hline & & & & &
\end{tabular}


Table 2: Variable Definitions and Descriptions

\begin{tabular}{|c|c|}
\hline Variable & Description \\
\hline Murder & $\begin{array}{l}\text { Murder rates per 100,000 inhabitants. Source: Ecuadorean National Insti- } \\
\text { tute of Statistics and Censuses. }\end{array}$ \\
\hline Asylum Seekers & $\begin{array}{l}\text { Total stock of asylum seekers per } 100 \text { inhabitants. Source: Ecuadorean } \\
\text { Ministry of Foreign Affairs. }\end{array}$ \\
\hline Bord FARC & $\begin{array}{l}\text { It is equal to FARC event rate for the three Ecuadorean bordering provinces. } \\
\text { It is zero for all non bordering provinces. }\end{array}$ \\
\hline FARC event rate & $\begin{array}{l}\text { It is the sum of all the FARC related conflict indicators for the Colombian } \\
\text { municipalities that share a border with Ecuador, weighted by the munici- } \\
\text { pal population. Source: Centro de Estudios sobre Desarrollo Económico } \\
\text { (CEDE). }\end{array}$ \\
\hline Bord FARC Nei & $\begin{array}{l}\text { It is equal to FARC Nei event rate for the three Ecuadorean bordering } \\
\text { provinces. It is zero for all non bordering provinces. }\end{array}$ \\
\hline FARC Nei event rate & $\begin{array}{l}\text { It is the sum of all the FARC related conflict indicators for all the munic- } \\
\text { ipalities that share a border with Ecuador plus their neighbours, weighted } \\
\text { by the municipal population. Source: Centro de Estudios sobre Desarrollo } \\
\text { Económico (CEDE). }\end{array}$ \\
\hline Bord All & $\begin{array}{l}\text { It is equal to All event rate for the three Ecuadorean bordering provinces. It } \\
\text { is zero for all non bordering provinces. }\end{array}$ \\
\hline All event rate & $\begin{array}{l}\text { It is the sum of all the FARC, ELN and AUC conflict indicators for all } \\
\text { the municipalities that share a border with Ecuador plus their neighbours, } \\
\text { weighted by the municipal population. Source: Centro de Estudios sobre } \\
\text { Desarrollo Económico (CEDE). }\end{array}$ \\
\hline Bord All Nei & $\begin{array}{l}\text { It is equal to All Nei event rate for the three Ecuadorean bordering } \\
\text { provinces. It is zero for all non bordering provinces. }\end{array}$ \\
\hline All Nei event rate & $\begin{array}{l}\text { It is the sum of all the FARC, ELN and AUC conflict indicators for all } \\
\text { the municipalities that share a border with Ecuador plus their neighbours, } \\
\text { weighted by the municipal population. Source: Centro de Estudios sobre } \\
\text { Desarrollo Económico (CEDE). }\end{array}$ \\
\hline Bord FARC Het & $\begin{array}{l}\text { It is equal to FARC Het event rate for the three Ecuadorean bordering } \\
\text { provinces. It is zero for all non bordering provinces. }\end{array}$ \\
\hline FARC Het event rate & $\begin{array}{l}\text { For each of the three Ecuadorean bordering provinces, we sum all the FARC } \\
\text { conflict indicators that refer to only the Colombian municipalities that share } \\
\text { a border with each Ecuadorean province. Then we weight by the munic- } \\
\text { ipal population. Source: Centro de Estudios sobre Desarrollo Económico } \\
\text { (CEDE). }\end{array}$ \\
\hline Bord All Het & $\begin{array}{l}\text { It is equal to All Het event rate for the three Ecuadorean bordering } \\
\text { provinces. It is zero for all non bordering provinces. }\end{array}$ \\
\hline
\end{tabular}


All Het event rate For each of the three Ecuadorean bordering provinces, we sum all the FARC, ELN and AUC conflict indicators for only the Colombian municipalities that share a border with each Ecuadorean province. Then we weight by the municipal population. Source: Centro de Estudios sobre Desarrollo Económico (CEDE).

Bord FARC Inv It is equal to FARC event rate multiplied by the inverse of the average distance from the border with Colombia. Source: Centro de Estudios sobre Desarrollo Económico (CEDE) and Google Maps.

Bord FARC Nei Inv It is equal to Bord FARC Nei multiplied by the inverse of the average distance from the border with Colombia. Source: Centro de Estudios sobre Desarrollo Económico (CEDE) Google Maps.

Bord All Inv It is equal to All event rate multiplied by the inverse of the average distance from the border with Colombia. Source: Centro de Estudios sobre Desarrollo Económico (CEDE) and Google Maps.

Density Density of population. Source: Ecuadorean National Institute of Statistics
and Censuses.

\begin{tabular}{ll}
\hline Male Population & $\begin{array}{l}\text { Percentage of male population on total population. Source: Ecuadorean } \\
\text { National Institute of Statistics and Censuses. }\end{array}$ \\
\hline Young Population & $\begin{array}{l}\text { Percentage of young people on total population. Source: Ecuadorean Na- } \\
\text { tional Institute of Statistics and Censuses. }\end{array}$ \\
\hline Young Male & $\begin{array}{l}\text { Interaction term between Male and Young. Source: Own calculation based } \\
\text { on Ecuadorean National Institute of Statistics and Censuses. }\end{array}$ \\
\hline Income Proxy & $\begin{array}{l}\text { Number of newly registered car per 100,000 inhabitants. Source: } \\
\text { Ecuadorean National Institute of Statistics and Censuses. }\end{array}$ \\
\hline $\begin{array}{l}\text { Prisoners } \\
\text { Instrument Table } 1,4,5\end{array}$ & $\begin{array}{l}\text { Number of prisoners per 1,000 inhabitants. Source: Ecuadorean Ministry } \\
\text { of Justice. }\end{array}$ \\
\hline $\begin{array}{l}\text { Instrument Table } \\
\text { col. } 2\end{array}$ & $\begin{array}{l}\text { Inverse of the average distance of the centroid of the Ecuadorean province } \\
\text { to the three frontiers multiplied by the FARC event rate for the province } \\
\text { of La Guajira. Source: Centro de Estudios sobre Desarrollo Económico } \\
\text { (CEDE) and Google Maps. }\end{array}$ \\
\hline $\begin{array}{l}\text { Instrument Table 5, } 5 \\
\text { col. } 3\end{array}$ & $\begin{array}{l}\text { Inverse of the average distance of the centroid of the Ecuadorean province } \\
\text { to the three frontiers multiplied by the sum of hectares manually eradi- } \\
\text { cated and aerially fumigated weighted by the total number of hectares cul- } \\
\text { tivated with coca leaves in all Colombia but the bordering municipalities } \\
\text { with Ecuador. Source: google maps and }\end{array}$ \\
\hline $\begin{array}{l}\text { Inverse of the average distance of the centroid of the Ecuadorean province } \\
\text { to the three frontiers multiplied by the sum of hectares manually eradicated } \\
\text { and aerially fumigated weighted by the total number of hectares cultivated } \\
\text { with coca leaves in the province of La Guajira. Source: google maps and }\end{array}$ \\
\hline
\end{tabular}


Instrument Table 9 Inverse of the average distance of the centroid of the Ecuadorean province to the three frontiers multiplied by the sum of hectares manually eradicated and aerially fumigated weighted by the total number of hectares cultivated with coca leaves in all Colombia. Source: google maps and

Table 3: Correlation Coefficient between GDP and Stock of Vehicles

\begin{tabular}{|c|c|c|c|c|c|c|c|c|c|c|}
\hline Province & Azuay & Bolívar & Cañar & $\mathrm{Carchi}^{\dagger}$ & Chimborazo & Cotopaxi & El Oro & Esmeraldas $^{\dagger}$ & Guayas & Imbabura \\
\hline Correlation & & & & & & GDP & & & & \\
\hline CAR & 0.069 & 0.525 & 0.052 & 0.079 & 0.959 & 0.972 & 0.960 & 0.875 & 0.854 & 0.938 \\
\hline Province & Loja & Los Ríos & Manabí & Morona Santiago & Napo & Pastaza & Pichincha & Tungurahua & Zamora Chinchipe & Sucumbíos ${ }^{\dagger}$ \\
\hline Correlation & & & & & & GDP & & & & \\
\hline CAR & 0.907 & 0.689 & 0.950 & 0.985 & 0.987 & 0.964 & 0.934 & 0.890 & 0.965 & 0.927 \\
\hline
\end{tabular}

Table 4: Asylum Seekers Spillover- OLS

\begin{tabular}{lccc}
\hline & $(1)$ & $(2)$ & $(3)$ \\
& Murder Rate & Murder Rate & Murder Rate \\
\hline Asylum Seekers & $-0.783^{* *}$ & $-1.009^{* * *}$ & -0.373 \\
& {$[0.335]$} & {$[0.271]$} & {$[0.243]$} \\
Density & -0.049 & -0.059 & -0.027 \\
& {$[0.059]$} & {$[0.171]$} & {$[0.062]$} \\
Male Population & 6.042 & 14.006 & $9.162^{*}$ \\
& {$[4.748]$} & {$[8.247]$} & {$[4.568]$} \\
Young Population & 7.996 & 20.812 & $14.977^{*}$ \\
& {$[8.275]$} & {$[12.493]$} & {$[8.075]$} \\
Young Male & -0.16 & -0.407 & $-0.298^{*}$ \\
& {$[0.163]$} & {$[0.246]$} & {$[0.160]$} \\
Income & -0.001 & -0.001 & \\
& {$[0.001]$} & {$[0.002]$} & \\
Prisoners & -0.295 & -0.257 & \\
& {$[0.423]$} & {$[0.618]$} & \\
Observations & 260 & 220 & 320 \\
R-squared & 0.281 & 0.142 & 0.241 \\
Period & $2000-2012$ & $1997-2010$ & $1997-2012$ \\
Year FE & $\checkmark$ & $\checkmark$ & $\checkmark$ \\
\hline
\end{tabular}

Notes: $(* * *)$ Indicates significance at the $1 \%$ level; $(* *)$ Significance at the $5 \%$ level and $(*)$ Significant at the $10 \%$ level. Standard Errors are reported in square brackets and are clustered at the provincial level to account for heteroskedasticity and serial correlation. The dependent variable is the homicides rate at the provincial level per 100,000 inhabitants. Asylum seekers is the stock of asylum seekers per 100 inhabitants. Please refer to Section 3 and Table 2 for variables descriptions and definitions. 
Table 5: Asylum Seekers Spillover- 2SLS

\begin{tabular}{|c|c|c|c|c|c|}
\hline & $\begin{array}{c}(1) \\
\text { Murder } \\
\text { Aereal-Manua } \\
\text { w/o Border }\end{array}$ & $\begin{array}{c}(2) \\
\text { Murder } \\
\text { Aereal-Manuc } \\
\text { La Guajira }\end{array}$ & $\begin{array}{c}(3) \\
\text { Murder } \\
\text { eereal-Manua } \\
\text { All }\end{array}$ & $\begin{array}{c}\text { (4) } \\
\text { Murder } \\
\text { Aereal-Manuo } \\
\text { w/o Border }\end{array}$ & $\begin{array}{c}(5) \\
\text { Murder } \\
\text { Aereal-Manual } \\
\text { w/o Border }\end{array}$ \\
\hline Asylum Seekers & $\begin{array}{c}-1.364 * * * \\
{[0.492]}\end{array}$ & $\begin{array}{l}-2.228 * \\
{[1.297]}\end{array}$ & $\begin{array}{c}-1.541 * * \\
{[0.639]}\end{array}$ & $\begin{array}{c}-0.947 * * \\
{[0.477]}\end{array}$ & $\begin{array}{c}-0.827 * * \\
{[0.362]}\end{array}$ \\
\hline $\begin{array}{l}\text { Period } \\
\text { Kleibergen-Paap F-Statistic }\end{array}$ & $\begin{array}{c}2000-2012 \\
13.46\end{array}$ & $\begin{array}{c}2000-2012 \\
11.82\end{array}$ & $\begin{array}{c}2000-2012 \\
10.68\end{array}$ & $\begin{array}{c}1997-2010 \\
7.69\end{array}$ & $\begin{array}{c}1997-2012 \\
9.7\end{array}$ \\
\hline \multicolumn{6}{|c|}{ First Stage } \\
\hline Instrument & $\begin{array}{c}0.009 * * * \\
{[0.002]}\end{array}$ & $\begin{array}{c}4.281 * * * \\
{[1.248]}\end{array}$ & $\begin{array}{c}0.006 * * * \\
{[0.002]}\end{array}$ & $\begin{array}{c}0.009 * * * \\
] 0.002]\end{array}$ & $\begin{array}{c}0.011 * * * \\
{[0.004]}\end{array}$ \\
\hline $\begin{array}{l}\text { Observations } \\
\text { R-squared } \\
\text { Controls } \\
\text { Period } \\
\text { Year FE }\end{array}$ & $\begin{array}{c}260 \\
0.565 \\
\checkmark \\
2000-2012 \\
\checkmark\end{array}$ & $\begin{array}{c}260 \\
0.453 \\
\checkmark \\
2000-2012 \\
\checkmark\end{array}$ & $\begin{array}{c}260 \\
0.523 \\
\checkmark \\
2000-2012 \\
\checkmark\end{array}$ & $\begin{array}{c}260 \\
0.565 \\
\checkmark \\
1997-2010 \\
\checkmark\end{array}$ & $\begin{array}{c}300 \\
0.516 \\
\checkmark \\
1997-2012 \\
\checkmark\end{array}$ \\
\hline
\end{tabular}

Notes: (***) Indicates significance at the $1 \%$ level; (**) Significance at the 5\% level and (*) Significant at the $10 \%$ level. Standard Errors are reported in square brackets and are clustered at the provincial level to account for heteroskedasticity and serial correlation. The dependent variable is the homicides rate at the provincial level per 100,000 inhabitants. Asylum seekers is the stock of asylum seekers per 100 inhabitants. Please refer to Section 3 and Table 2 for variables descriptions and definitions.

Table 6: Conflict Spillover- Baseline OLS

\begin{tabular}{|c|c|c|c|c|c|c|}
\hline & $\begin{array}{c}(1) \\
\text { Murder } \\
\text { Rate }\end{array}$ & $\begin{array}{c}(2) \\
\text { Murder } \\
\text { Rate }\end{array}$ & $\begin{array}{c}(3) \\
\text { Murder } \\
\text { Rate }\end{array}$ & $\begin{array}{c}(4) \\
\text { Murder } \\
\text { Rate }\end{array}$ & $\begin{array}{c}(5) \\
\text { Murder } \\
\text { Rate }\end{array}$ & $\begin{array}{c}(6) \\
\text { Murder } \\
\text { Rate }\end{array}$ \\
\hline Bord FARC & $\begin{array}{c}0.014 \\
{[0.054]}\end{array}$ & & & & & \\
\hline Bord FARC Nei & & $\begin{array}{c}0.018 \\
{[0.055]}\end{array}$ & & & & \\
\hline Bord All & & & $\begin{array}{c}0.011 \\
{[0.052]}\end{array}$ & & & \\
\hline Bord All Nei & & & & $\begin{array}{c}0.016 \\
{[0.054]}\end{array}$ & & \\
\hline Bord FARC Het & & & & & $\begin{array}{c}0.008 \\
{[0.022]}\end{array}$ & \\
\hline Bord All Het & & & & & & $\begin{array}{c}0.009 \\
{[0.029]}\end{array}$ \\
\hline Observations & 280 & 280 & 280 & 280 & 280 & 280 \\
\hline R-squared & 0.181 & 0.181 & 0.181 & 0.181 & 0.182 & 0.181 \\
\hline Period & $1997-2010$ & 1997-2010 & 1997-2010 & $1997-2010$ & $1997-2010$ & $1997-2010$ \\
\hline Controls & $\checkmark$ & $\checkmark$ & $\checkmark$ & $\checkmark$ & $\checkmark$ & $\checkmark$ \\
\hline Year FE & $\checkmark$ & $\checkmark$ & $\checkmark$ & $\checkmark$ & $\checkmark$ & $\checkmark$ \\
\hline
\end{tabular}

Notes: $(* * *)$ Indicates significance at the $1 \%$ level; $(* *)$ Significance at the $5 \%$ level and $(*)$ Significant at the $10 \%$ level. Standard Errors are reported in square brackets and are clustered at the provincial level to account for heteroskedasticity and serial correlation. The dependent variable is the homicides rate at the provincial level per 100,000 inhabitants. Please refer to Section 3 and Table 2 for variables descriptions and definitions. 
Table 7: Conflict Spillover-Robustness Checks I

\begin{tabular}{|c|c|c|c|c|c|c|c|}
\hline & $\begin{array}{c}(1) \\
\text { Murder } \\
\text { Bord FARC } \\
\text { Inv }\end{array}$ & $\begin{array}{c}(2) \\
\text { Murder } \\
\text { Bord FARC } \\
\text { Inv nei }\end{array}$ & $\begin{array}{l}(3) \\
\text { Murder } \\
\text { Bord } \\
\text { FARC } 4\end{array}$ & $\begin{array}{l}\text { (4) } \\
\text { Murder } \\
\text { Bord } \\
\text { FARC } 5\end{array}$ & $\begin{array}{c}(5) \\
\text { Murder } \\
\text { Bord FARC } \\
\text { FARC \& Other }\end{array}$ & $\begin{array}{c}(6) \\
\text { Murder } \\
\text { Untill } \\
2008\end{array}$ & $\begin{array}{c}(7) \\
\text { Murder } \\
\text { FARC All } \\
\text { All Colombia }\end{array}$ \\
\hline Regressor & $\begin{array}{c}1.205 \\
{[12.559]}\end{array}$ & $\begin{array}{c}0.159 \\
{[13.198]}\end{array}$ & $\begin{array}{c}0.006 \\
{[0.041]}\end{array}$ & $\begin{array}{c}-0.003 \\
{[0.034]}\end{array}$ & $\begin{array}{c}0.006 \\
{[0.014]}\end{array}$ & $\begin{array}{c}0.089 \\
{[0.070]}\end{array}$ & $\begin{array}{c}0.180 \\
{[0.310]}\end{array}$ \\
\hline Observations & 280 & 280 & 280 & 280 & 280 & 220 & 280 \\
\hline R-squared & 0.180 & 0.180 & 0.180 & 0.180 & 0.183 & 0.236 & 0.189 \\
\hline Controls & $\checkmark$ & $\checkmark$ & $\checkmark$ & $\checkmark$ & $\checkmark$ & $\checkmark$ & $\checkmark$ \\
\hline Period & $1997-2010$ & $1997-2010$ & $997-2010$ & $997-2010$ & $1997-2010$ & 1997-2008 & $1997-2010$ \\
\hline Year FE & $\checkmark$ & $\checkmark$ & $\checkmark$ & $\checkmark$ & $\checkmark$ & $\checkmark$ & $\checkmark$ \\
\hline
\end{tabular}

Notes: (***) Indicates significance at the $1 \%$ level; $(* *)$ Significance at the $5 \%$ level and (*) Significant at the $10 \%$ level. Standard Errors are reported in square brackets and are clustered at the provincial level to account for heteroskedasticity and serial correlation. The dependent variable is the homicides rate at the provincial level per 100,000 inhabitants. Please refer to Section 3 and Table 2 for variables descriptions and definitions.

Table 8: Conflict Spillover-Robustness Checks II

\begin{tabular}{|c|c|c|c|c|c|c|}
\hline & $\begin{array}{c}(1) \\
\text { Murder } \\
\text { Prisoners \& Income }\end{array}$ & $\begin{array}{l}(2) \\
\text { Murder } \\
R E\end{array}$ & $\begin{array}{c}(3) \\
\text { Murder } \\
\text { Wild bootstrap }\end{array}$ & $\begin{array}{c}(4) \\
\text { Murder } \\
\text { First Lag }\end{array}$ & $\begin{array}{c}(5) \\
\text { Murder } \\
\text { Second Lag }\end{array}$ & $\begin{array}{l}\text { (6) } \\
\text { Murder } \\
\text { All lags }\end{array}$ \\
\hline Bord FARC & $\begin{array}{c}-0.029 \\
{[0.046]}\end{array}$ & $\begin{array}{c}0.031 \\
{[0.060]}\end{array}$ & $\begin{array}{c}0.014 \\
{[0.045]}\end{array}$ & & & $\begin{array}{l}-0.055^{*} \\
{[0.027]}\end{array}$ \\
\hline L.Bord FARC & & & & $\begin{array}{c}0.027 \\
{[0.036]}\end{array}$ & & $\begin{array}{c}0.042 \\
{[0.094]}\end{array}$ \\
\hline L.L.Bord FARC & & & & & $\begin{array}{c}0.007 \\
{[0.068]}\end{array}$ & $\begin{array}{c}-0.001 \\
{[0.149]}\end{array}$ \\
\hline Obse & 220 & 280 & 280 & 260 & 240 & 240 \\
\hline R-squared & 0.103 & 0.3923 & 0.1808 & 0.154 & 0.108 & 0.113 \\
\hline Period & $2000-2010$ & $1997-2010$ & 1997-2010 & $1998-2010$ & 1999-2010 & 1999-2010 \\
\hline Controls & $\checkmark$ & $\checkmark$ & $\checkmark$ & $\checkmark$ & $\checkmark$ & $\checkmark$ \\
\hline Year FE & $\checkmark$ & $\checkmark$ & $\checkmark$ & $\checkmark$ & $\checkmark$ & $\checkmark$ \\
\hline
\end{tabular}

Notes: (***) Indicates significance at the $1 \%$ level; (**) Significance at the $5 \%$ level and (*) Significant at the $10 \%$ level. Standard Errors are reported in square brackets and are clustered at the provincial level to account for heteroskedasticity and serial correlation. The dependent variable is the homicides rate at the provincial level per 100,000 inhabitants. Please refer to Section 3 and Table 2 for variables descriptions and definitions. 
Table 9: Conflict Spillover-2SLS

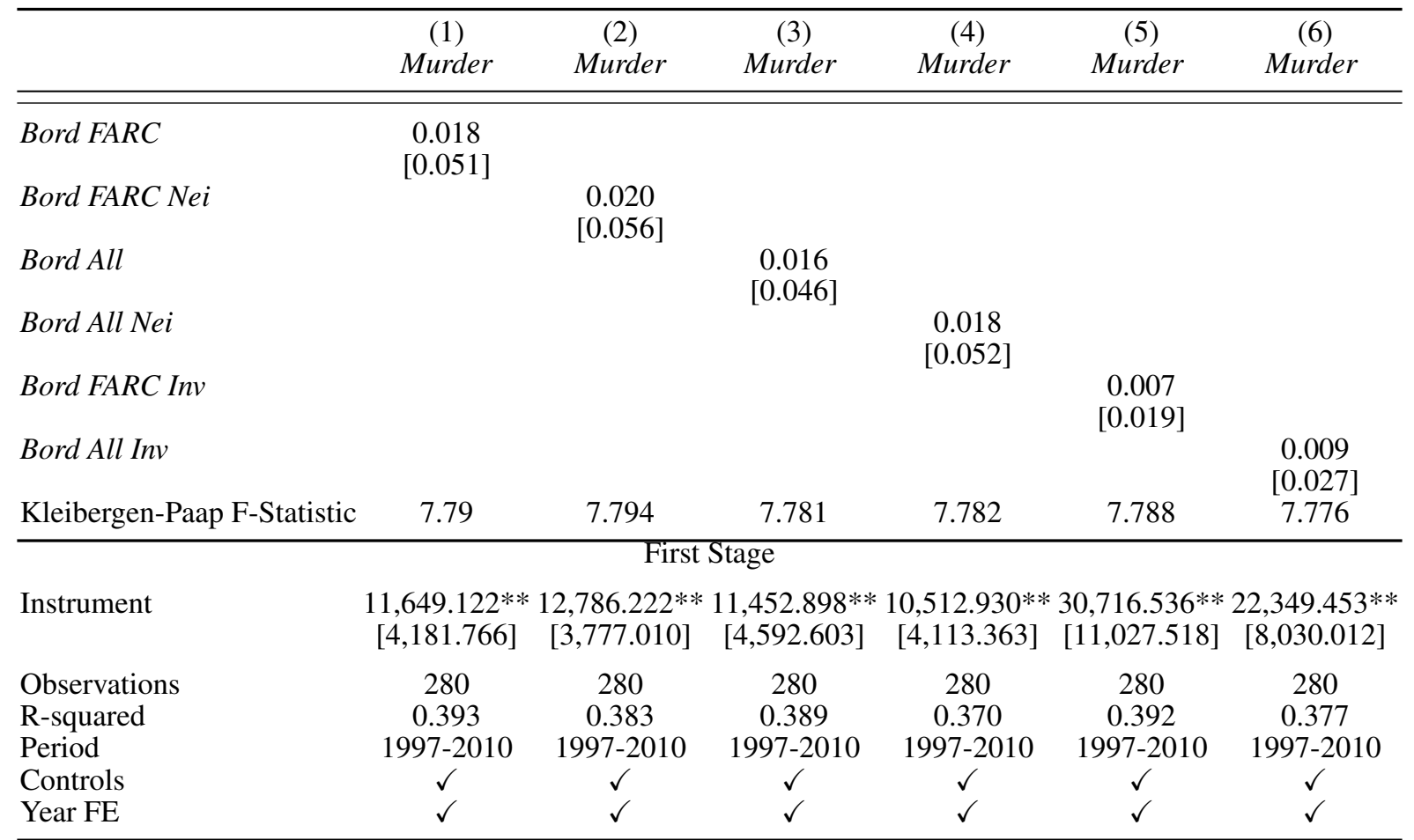

Notes: (***) Indicates significance at the $1 \%$ level; (**) Significance at the 5\% level and (*) Significant at the $10 \%$ level. Standard Errors are reported in square brackets and are clustered at the provincial level to account for heteroskedasticity and serial correlation. The dependent variable is the homicides rate at the provincial level per 100,000 inhabitants. Please refer to Section 3 and Table 2 for variables descriptions and definitions. 